DEPARTMENT OF THE INTERIOR

UNITED STATES GEOLOGICAL, SURVEY

GEORGE OTIS SMITH, DiRECTOR

Professional Paper 85-B

\title{
THE MUD LUMPS AT THE MOUTHS OF THE MISSISSIPPI
}

BY

\author{
ÉUGENE WESLEY SHAW
}

Published December 20, 1913

WASHINGTON

GOVERNMENT PRINTING OFFICE

1913 


\section{CONTENTS.}

Page.

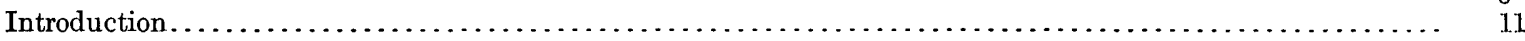

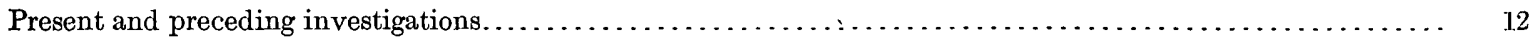

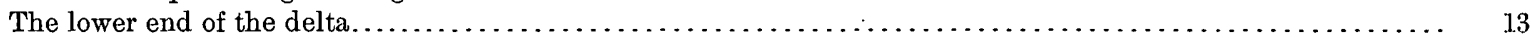

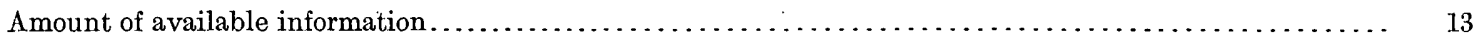

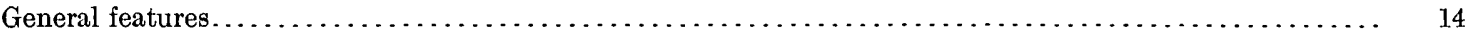

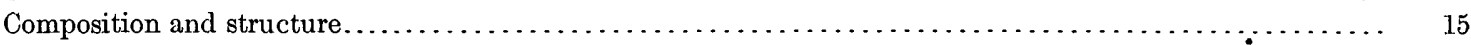

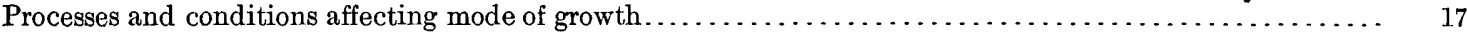

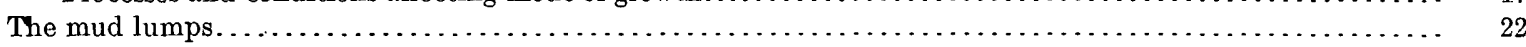

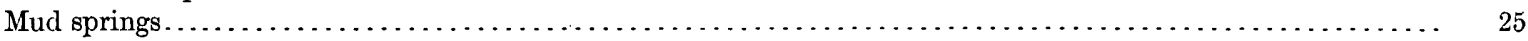

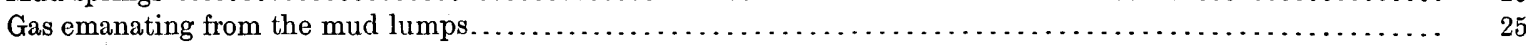

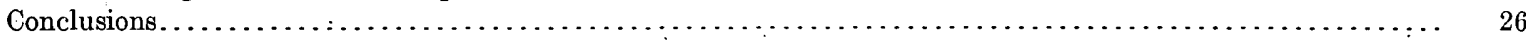

\section{ILLUSTRATIONS.}

Plate I. $A$, Mud-lump islands 2 to 3 miles southeast of Pass a Loutre Lighthouse; $B$, View about 3 miles seaward from end of Southwest Pass; $C$, Mud spring at top of wave-cut cliff on mud lump 3 miles

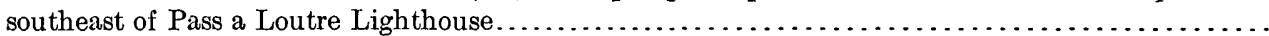

II. Map of the bar and vicinity at the outer end of Southwest Pass, showing changes effected in the

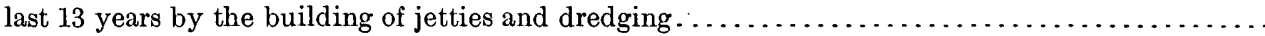

III. $A$, Wave-cut cliff on Gibraltar mud lump, Red Fish Bay; $B$, Mud lump $3 \frac{1}{2}$ miles southeast of Pass à

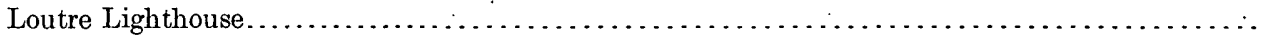

FIGURE 1. Sketches showing depth and condition of channel on successive dates and development of mud

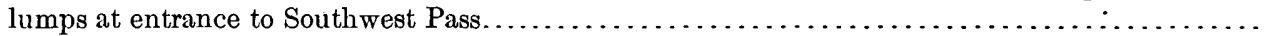

2. Sketch map of lower end of Delta of the Mississippi, showing approximately areas of land and water

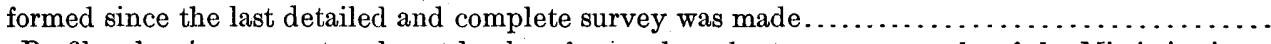

3. A, Profiles showing present and past land surface and sea bottom near mouths of the Mississippi....

4. Cross section from south-southwest to north-northeast through Port Eads and Balize..............

5. Two charts of the entrance to Southwest Pass.

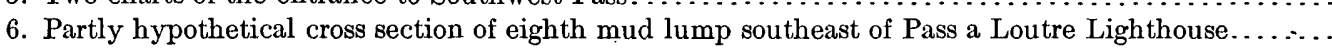
II 


\title{
THE MUD LUMPS AT THE MOUTHS OF THE MISSISSIPPI.
}

\author{
By Eugene Wesley Shaw
}

\section{INTRODUCTION.}

The territory within a mile or two of each of the mouths of the Mississippi is characterized by large swellings or upheavals of tough bluish-gray clay, to which has been applied the name "mud lumps." Many of these mud lumps rise just offshore and form islands having a surface extent of an acre or more and a height of 5 or 10 feet (see Pl. I, A), but some do not reach the water surface. They rise and subside at irregular rates, some of them suddenly, and they have been spoken of as the evil genii of the Passes, for constant vigilance is necessary to keep charts of these waters properly corrected. (See fig. 1.)

Almost all the mud lumps occur near bars at the mouths of the river. These bars are great piles of sediment which accumulate where the branches or passes of the river enter the sea. Their crests are naturally only about 10 feet under water, whereas for 200 miles upstream the river is 50 to 200 feet deep, but the United States engineers have made channels 30 to 35 feet deep and several hundred feet wide across the bars at South and Southwest passes. The natural bar of Southwest Pass and the changes made in it by the engineers are illustrated in Plate II.

An immense amount of traffic finds its natural course southward and eastward from the north side of the Gulf of Mexico, and this commerce, which is certain to augment, must be protected and the approaches to New Orleans improved and even their present large capacity increased. New Orleans, although over 100 miles from the sea, is now the fifteenth largest city and the second largest port in the United States, so that the seaward outlet for her commerce is of vital importance.

The mud lumps are also of considerable

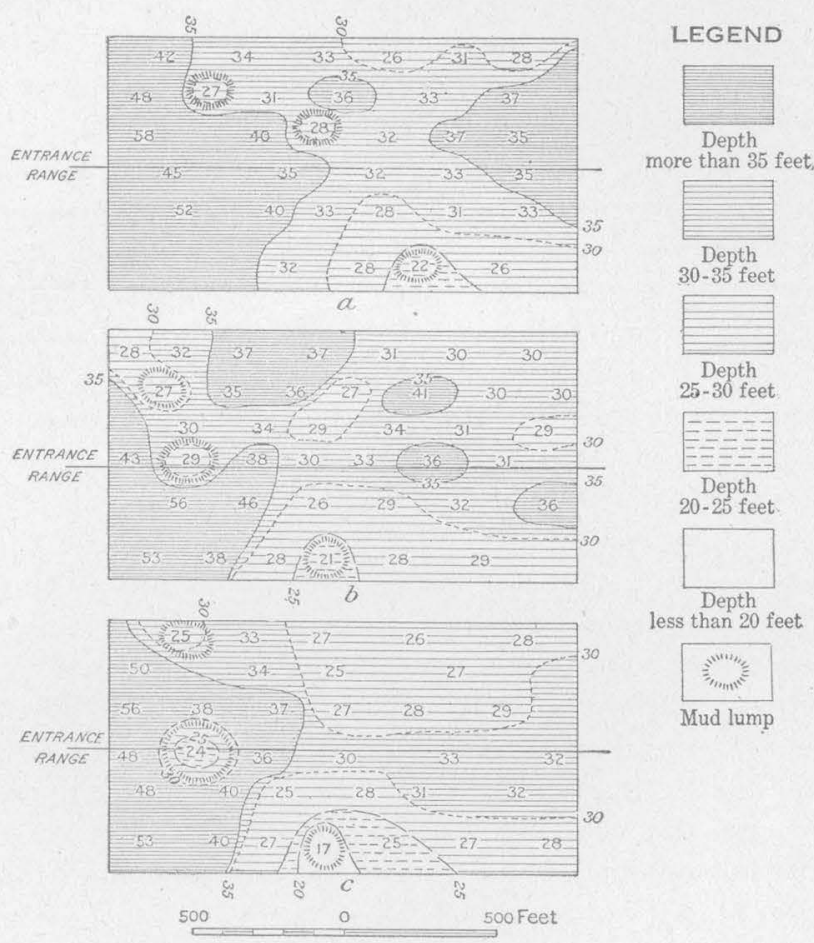

Figure 1.-Sketches showing depth and eondition of ehannel at different dates and development of mud lumps at entrance of Southwest Pass. From data furnished by United States Corps of Engineers. The area lies in the middle of the channel and just outside the jetties. Sketches $a, b$, and $c$ were prepared from soundings made A pr. 29, May 10, and May 19, respectively. One of the mud Iumps rose in the middle of the channel where, on A pr. 29, there was 45 feet of water but on May 19 only 23 feet. Apparently some of the lumps shifted slightly in position and others subsided while new ones rose near by. The shape of the bottom here at any particular time is a result of the work of the river, the activities of the mud lumps, and the Government dredging operations.

purely scientific interest, for their development is not included in the usual concept of delta growth, and although several hypotheses concerning them have been advanced, their cause must still be regarded as uncertain. 


\section{PRESENT AND PRECEDING INVESTIGATIONS.}

The present study of the mud lumps, which is a part of the Coastal Plain investigations of the United States Geological Survey, has been only begun, and this report is but a brief summary of existing knowledge of the mud lumps and of features and processes which may throw light on their origin. It includes some facts and ideas gathered in a few weeks spent at the mouth of the river in the fall of 1912 and the summer of 1913. On the first trip the United States engineers gave much assistance and furnished many important data, and on the second, through the courtesy of Dr. H. F. Moore, of the Bureau of Fisheries, the United States steamship Fish Hawk was made available for collecting samples of water and mud just offshore. T. Wayland Vaughan and others have furnished valuable suggestions and Prof. E. W. Hilgard and several members of the United States Engineer Corps and United States Geological Survey have very kindly read and criticized the manuscript.

Comparatively little geologic field work has been done on the problems of the Mississippi Delta or the mud lumps. Lyell and Hilgard have made the principal contributions, their results being set forth in several publications. Lyell's conclusions are summarized in his textbook, and Hilgard's in a recent paper entitled "A new development in the Mississippi delta," published in the Popular Science Monthly for March, 1912, and also in several papers published in the American Journal of Science in 1871. The engineering problems connected with the mud lumps have been extensively discussed, particularly in the annual reports of the United States engineers. The lumps are probably peculiar to the delta of the Mississippi, but, as Hilgard says, it seems remarkable that upheavals so extensive should escape discussion or even reference in most of the best textbooks on geology. Potonié, ${ }^{1}$ however, has described a growth similar, in some respects at least, to the mud lumps and concludes that it was produced by marsh gas, clay having flowed into the cavity as the gas escaped, making the island permanent.

Several hypotheses concerning the cause of the lumps are worthy of consideration, though few have been set forth in print. Volcanism, faulting, the accumulation of bodies of rock salt or sulphur or oil like laccoliths below the surface, and the forcing up of the clay by hydraulic pressure transmitted through water from higher points to the landward through inclosed porous strata seem to be out of the question as causes of the phenomenon. The two ideas most favored have been (1) that the lumps are upheaved by gas, and (2) that the pressure of the constantly increasing deposits of the delta has in some way caused the upheavals.

Hilgard contends that the mud lumps owe their existence to the pressure of a layer of sand and silt, perhaps 30 or 40 feet thick, on a thinner layer of very fluid mud below, which in turn rests upon a stratum that he calls Port Hudson clay-a deposit very different from any being formed to-day. He believes that just offshore much river-borne colloidal sediment is being flocculated by the salt of the sea and is slowly settling, forming a layer of sludge; that a more granular and compact layer is built out on this sludge, giving rise to an unstable condition; and finally that wherever the crust, so to speak, is weakest the sludge is forced up to the surface through the weight of the sand and silt. It thus becomes of prime importance to determine whether or not the bottom offshore is very fluid mud.

When Capt. James B. Eads proposed to put in jetties at the end of South Pass to cause the river to scour deeper and do some of the work that the dredges had been doing in keeping a navigable depth of water over the bar Hilgard wrote to Eads saying that if this plan were put into operation a deeper channel would be scoured, but that the scouring would weaken the crust of silt so much that the fluid mud from below would break up through, obstructing the channel more seriously than the fine sand of the bar. Eads had encountered considerable objection to his plan of building jetties, but he was a man of both means and determination and his final proposal to advance the funds for building the jetties and ask no reimbursement until the desired depth of water was obtained was accepted. He replied to Hilgard that a surcease from the heavy burden of dredging for 20 or 30 years would be worth the cost of the

1 Potonié, H., Eine im Ögelsee (Prov. Brandenburg) plötzlich neu entstandene Insel: K. preuss. geol. Landesanstalt zu Berlin Jahrb., Band 32, Teil 1, pp. 187-218, 1911. 


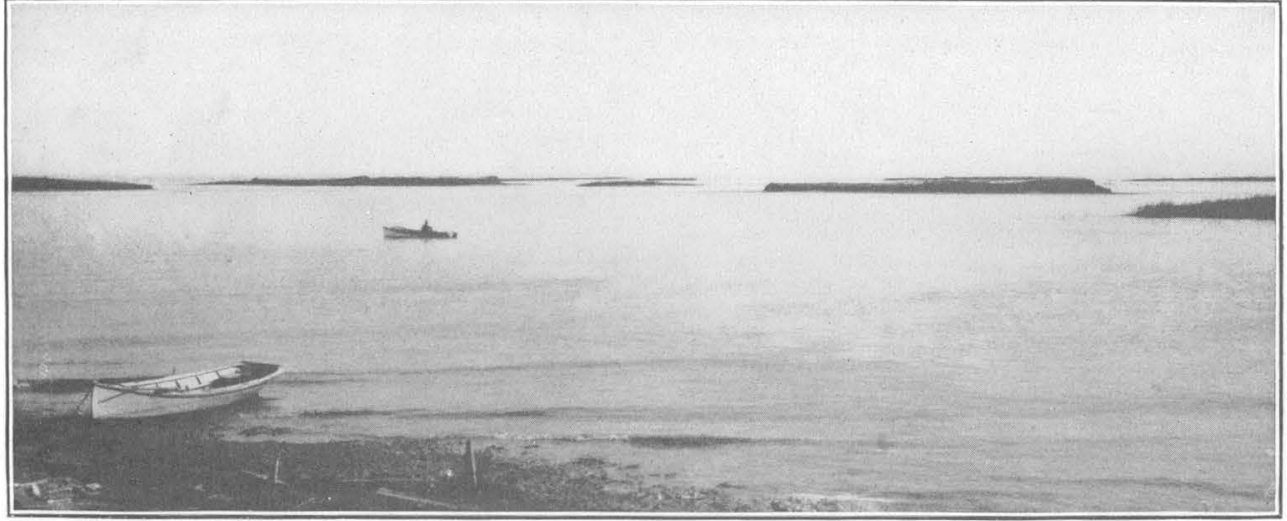

A. MUD-LUMP ISLANDS 2 TO 3 MILES SOUTHEAST OF PASS A LOUTRE LIGHTHOUSE.

All these islands have been formed in the last few years by the swelling up of portions of the sea floor, so recently that none of them are shown on the latest chart. Like other mud lumps they are comparatively flat-topped and concordant in height.

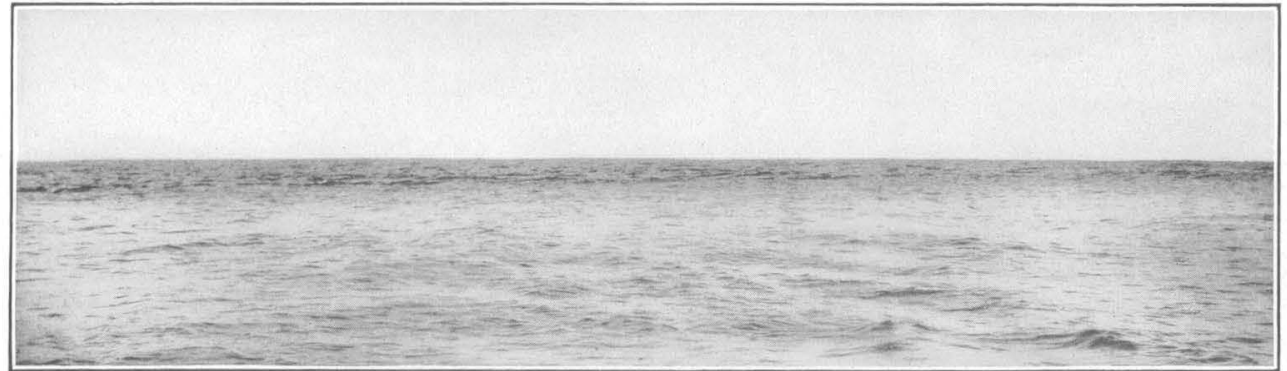

B. VIEW ABOUT 3 MILES SEAWARD FROM END OF SOUTHWEST PASS.

Showing light-colored, muddy river water in foreground and dark, clear sea water in distance. The boundary between the two is very sharp, and there seems to be also a difference in wave form between the clear and the muddy water.

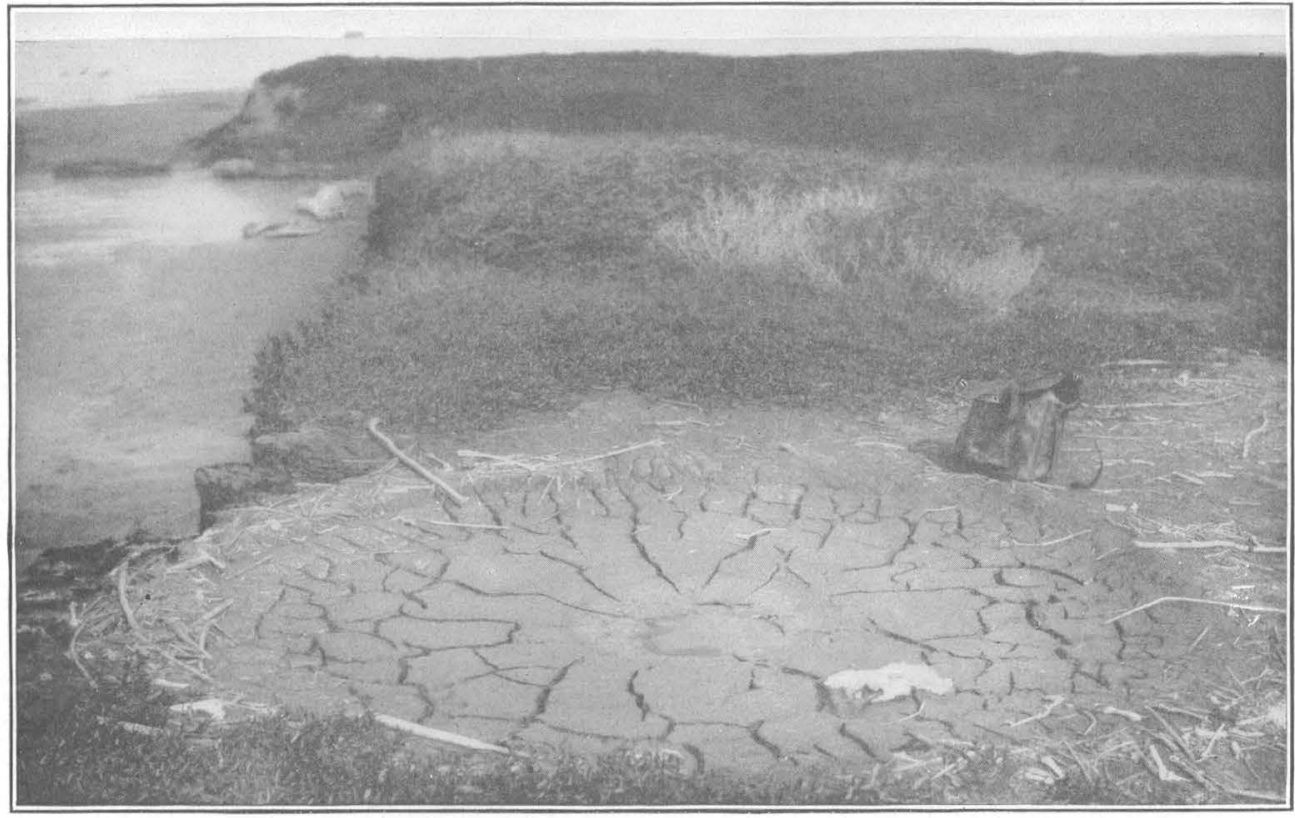

c. MUD SPRING AT TOP OF WAVE-CUT CLIFF ON MUD LUMP 3 MILES SOUTHEAST OF PASS A LOUTRE LIGHTHOUSE.

This and the other photographs were taken in the low-water season, when the springs and mud lumps are least active. To judge by the fact that the rim of the "crater" has been built un only a few inches the discharge from this spring, even when most active, is probably very slight. These spluttering, volcano-like gas-mud springs seem a fitting accompaniment to the weird, silent, and unforeboded rise and subsidence of the islands. 


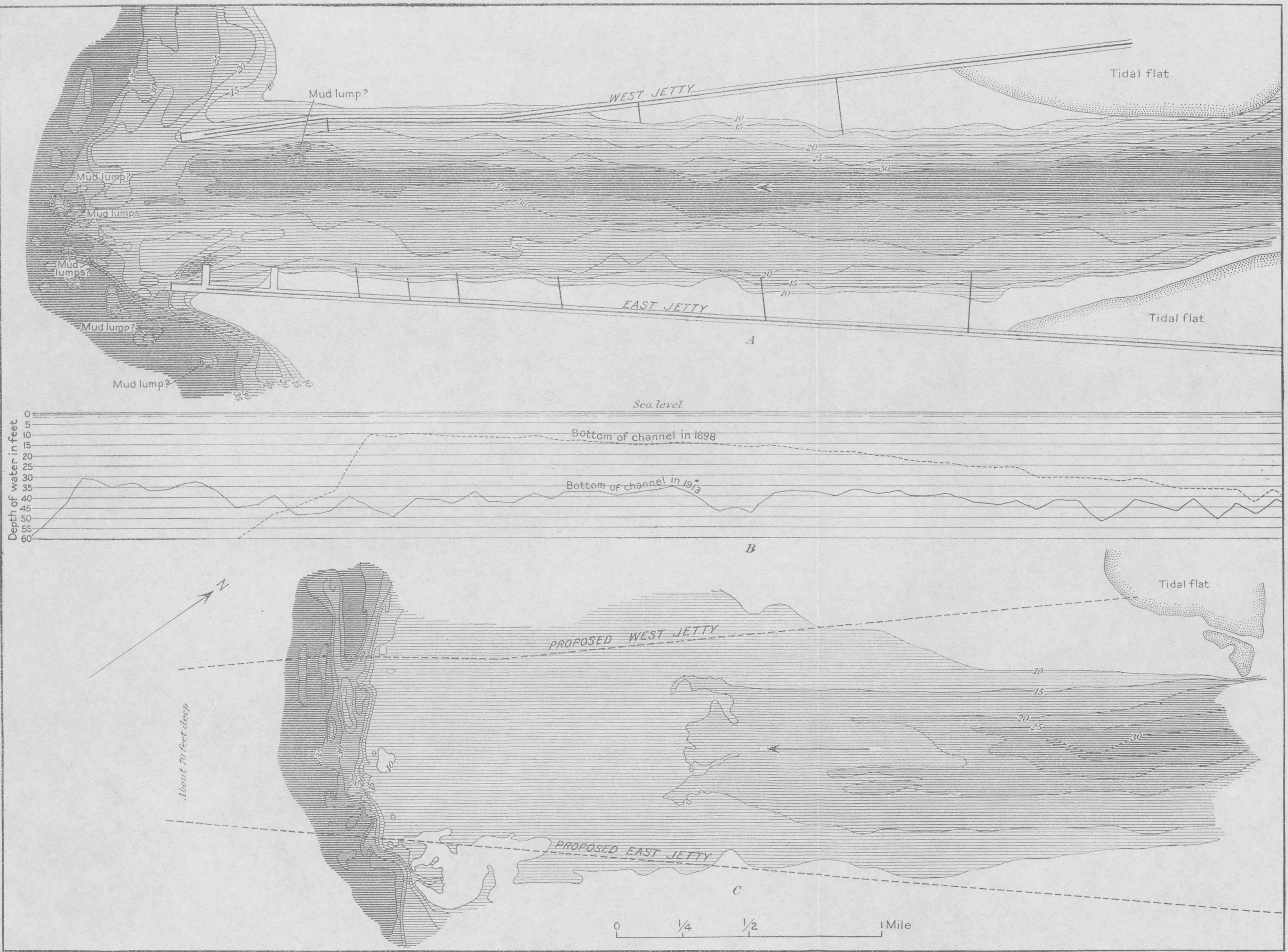

MAP OF THE BAR AT THE OUTER END OF SOUTHWEST PASS.

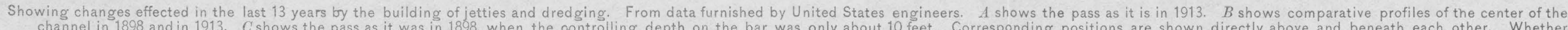
ny of the elevations on the crest of the bar in 1898 were mud lumps is not known, but the fact that at that place, which has since been deeply scoured, th bar, where in 1898 there was over 70 feet of water, mud lumps are numerous seem to militate against the idea that "mud lumps commonly arise in a pass immediately inside of the steep upstream slope of the 
jetties and begged Hilgard not to press his objection. Hilgard agreed but prophesied that mud lumps would appear within 30 or 40 years on the inner slope of the bar where the river was caused to scour most deeply. Forty years has passed and the appearance of a mud lump at the end of South Pass according to Hilgard's prophecy is the principal theme of his recent paper.

\section{THE TOWER END OF THE DELTA.}

\section{AMOUNT OF AVAILABLE INFORMATION.}

Geologists are exploring in greater or less detail about one-fourth of the earth's surface, the remaining three-fourths being covered with water. They have obtained much information concerning the underlying rocks and the geologic history of all lands but have learned so little of the sea bottom-both its underlying materials and its history in ages gone by-that the permanency of ocean basins is still a subject of discussion. The interpretation of ancient sedimentary deposits has reached an advanced stage, but not with the assistance of any large amount of exact detailed information on present depositional conditions and processes now in operation. Erosion has been studied in detail and the effects of its various factors have been carefully evaluated, but sedimentation appears not to have received its share of attention. The study of the composition, structure, and mode of growth of the Mississippi Delta is therefore of great interest, for here a new geologic formation is now developing and processes of sedimentation are operating rapidly and on a large scale.

The lower end of the Mississippi Delta seems to be a region much frequented but little known. Every year multitudes of people visit New Orleans, but travel is confined for the most part to the four or five main rail and water routes. Between these routes lie great areas of marsh which man has not put to his service and which are not often traversed either by natjuralists or by others. Perhaps it has been thought that the mode of growth of the Delta is so simple and so well understood that investigation would reveal nothing new. The prevailing ider seems to be that deltas are built up regularly by the addition of topset, foreset, and bottomset beds, and that this process and the constant shifting of the network of channels constitute about all that happens. But numerous facts-for example, the fact that the mouths of the Mississippi are apparently not shifting-do not accord with this idea.

Notwithstanding the fact that the region is in some respects an uncomfortable dwelling place it has many attractive features. Mosquitoes are somewhat troublesome, particularly a few miles back from the open sea, and sand flies are abundant along the coast at certain times of the year. The marshes are commonly too soft for travel of any kind, so that houses and walks are built on piles a few feet above the marsh, the interior of which would be almost inaccessible were it not for the passes and bayous that ramify it. But the discomforts are more than overbalanced by the features of interest, especially in the autumn. Orange groves border the river from New Orleans down almost to the Head of the Passes, below which hunting, trapping, fishing, and oyster growing occupy the time of most of those not engaged in Government work or as pilots. The region abounds in water fowl and in rabbits, muskrats, and raccoons. The proximity of the sea almost precludes oppressive heat and the temperature rarely, if ever, reaches the freezing point. Laborers, however, sometimes cease working in winter on account of cold winds. Large areas in the newer part of the Delta are not forested; indeed, all the plants of the region seem to be marching toward the sea by groups in orderly fashion.

The most striking evidence that the Delta is little known is that its geography is quite different from that indicated on the latest charts. (See fig. 2.) No less than 100 square miles of land is represented on these charts as water, and, what is still more remarkable, many square miles of water are shown as land. All the best maps of the lower end of the Delta show a deep indentation, called Garden Island Bay, between South Pass and Southeast Pass. As a matter of fact, there is only a small reentrant between these passes, and the maps were out of date 15 or 20 years ago. The reason for the inaccuracy is that the territory between the passes is not often visited and has not recently been surveyed. The coast chart has been corrected from time to time, but only from data concerning the traveled passes. 


\section{GENERAL FEATURES.}

In order to formulate working hypotheses concerning the mud lumps it seems necessary first to learn as much as possible of the composition, structure, and mode of growth of the Delta.

A considerable part of southern Louisiana is less than 10 feet above sea level and much of it is inundated every year, receiving at each inundation a greater or less amount of sediment. The land surface is also losing some material through solution and stream'transportation, but on the whole it is being gradually built up, or at least it was being built up before the levees were built and much of the flood water was shut out. Along the border of this flood plain lie other lowlands, only a few feet higher but having an aspect so different as to soil, vegetation, and form of suiface that they are easily distinguished. The highest land lies along the river,

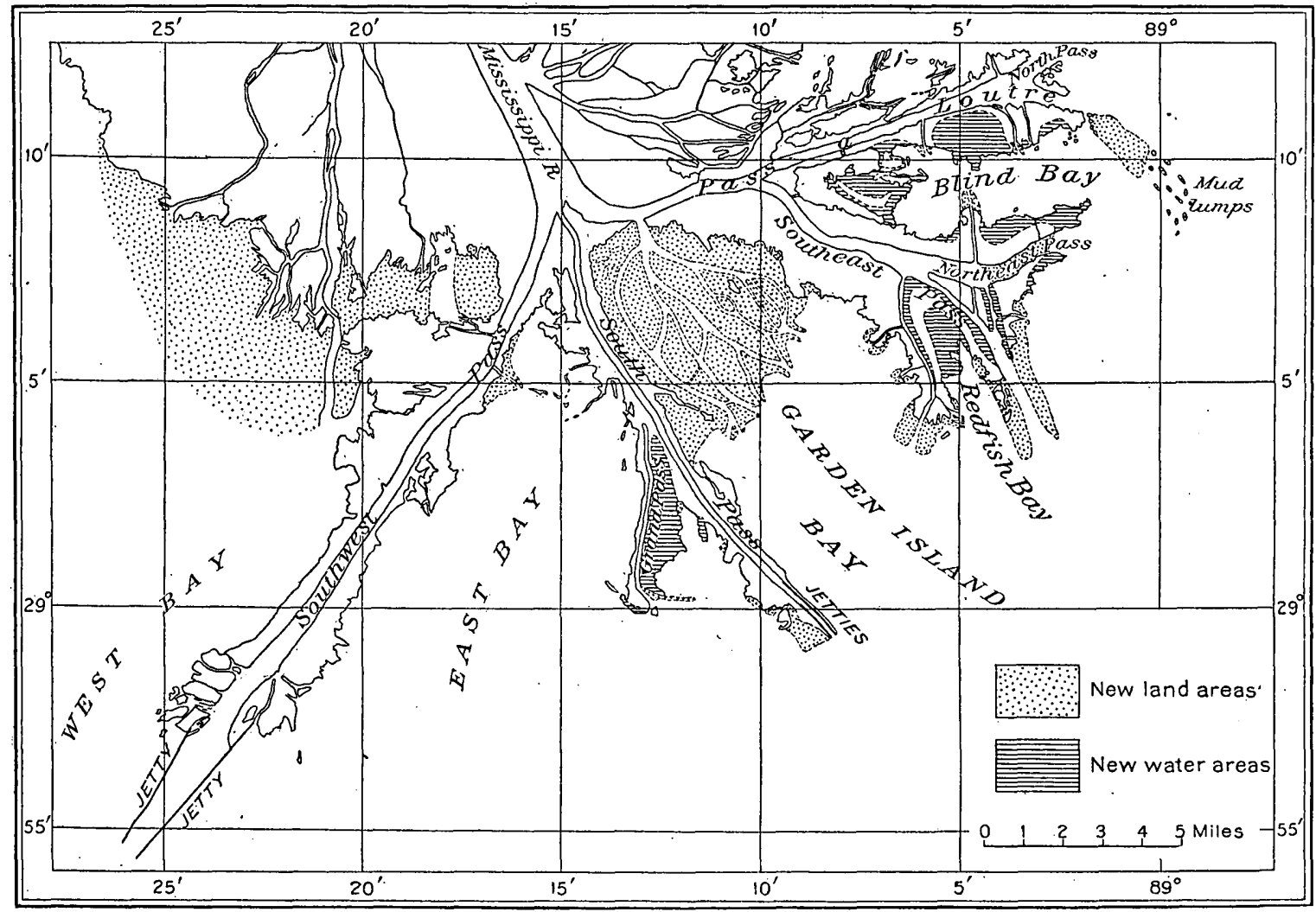

Figure 2--Sketch map of lower end of Delta of the Mississippi, showing approximately areas of land and water formed since the last detailed and complete survey was made. The coast chart has been corrected almost yearly for modifications in the territory immediately adjacent to the well-traveled passes, but not for the extensive changes that have taken place in the great marshes and bays between the passes. Although the Delta receives from the Mississippi about $400,000,000$ tons of sediment every year and its front is commonly said to be advancing into the sea at the rate of 340 feet a year, the sea is at many places encroaching on the land. The immense amount of new land that has recently been formed in Garden Island Bay is a result of a crevasse that was formed several years ago near the Head of the Passes.

the banks of which slope gradually from heights 10 to 15 feet above low water at New Orleans to sea level at the mouths of the river, and the high-water profile has a similar decline.

To an observer at the mouth of the river the idea that the region is a great dumping ground for a large part of the United States is most impressive. The land is being built out into the sea at an estimated average rate of about 300 feet a year, and although this estimate may be high, the rate is certainly rapid, as the constantly changing coast line and aspect of the vegetation bear witness. In some places it is much more rapid than others. In one place in Garden Island Bay the land appears to have advanced 2,000 feet in the spring of 1912.

Not only does the rate of advance differ from place to place, but the shore is in places actually retreating, not so much by sea erosion as by settling, which in places predominates over upbuilding. 
COMPOSITION AND STRUCTURE.

l.t appears that in general the upper 50 feet, at least, of the deposits near the mouth of the iver consist of thin layers of dark-blue clay and fine sand and a great many thin beds of intermediate character, ench of which grades into the adjacent beds. Layers of clay almost free from sand and beds composed of a mixture of clay and fine sand are common, and the mixture of clay and sand is much more rigid than nearly pure clay.

Some of the material falls no doubt into the class known as topset beds, and some of it belongs to the foreset beds. Knowledge sufficient to afford a basis for classifying the beds by their physical character is not yet available. The topset beds at the head of the passes are probably at least 10 and not more than 100 feet thick, and along any pass they probably thin toward the coast. The deposits between the passes are more difficult to classify. The topset beds are on the whole most sandy and resistant near the passes and most clayey in the bays and marshes between; the foreset beds appear also to be in general coarsest near the passes, but the amount of sand they contain decreases not only laterally but downward for 40 or 50 feet, the lower material having no doubt been deposited in deep water some distance offshore. But there appear to be sandy layers throughout both topset and foreset beds, and all the strata are more or less lenticular.

The mechanical character of the sediment being deposited near the mouth of the river is shown in the following table:

Mechanical analyses of samples of earth obtained near the mouth of Mississippi River.

[Analyses mado by Bureau of Soils, United States Department of Agriculture.]

\begin{tabular}{|c|c|c|c|c|c|c|c|c|c|}
\hline No. & Locality. & Depth. & $\begin{array}{l}\text { Fine } \\
\text { gravel } \\
\text { (2 to } 1 \\
\text { mm.). }\end{array}$ & $\begin{array}{l}\text { Coarse } \\
\text { sand } \\
\text { (1 to } 0.5 \\
\text { mm.). }\end{array}$ & $\begin{array}{c}\text { Medium } \\
\text { sand } \\
(0.5 \text { to } \\
0.25 \mathrm{~mm} .)\end{array}$ & $\begin{array}{c}\text { Fine } \\
\text { sand } \\
(0.25 \text { to } \\
0.1 \mathrm{~mm} .)\end{array}$ & $\begin{array}{c}\text { Very fine } \\
\text { sand } \\
(0.1 \text { to } \\
0.05 \mathrm{~mm} .)\end{array}$ & $\begin{array}{c}\text { Silt }(0.05 \\
\text { to } 0.005 \\
\mathrm{~mm} .) .\end{array}$ & $\begin{array}{l}\text { Clay } \\
(0.005 \\
\text { mm. or } \\
\text { less). }\end{array}$ \\
\hline 20106 & I millo cast of Burrwood.. & 5 feet below surface.. & 0.0 & 0.1 & 0.2 & 5.5 & 64.0 & 27.0 & 2.9 \\
\hline 20107 & 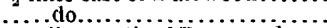 & 33 feet below surface....... & .0 & .0 & .1 & 1.4 & 1.4 & 48.9 & 48.0 \\
\hline 20108 & 3 miles north of Burrwood.... & $9 \frac{1}{2}$ to 10 feet below surface.. & .0 & .0 & .1 & .8 & 20.6 & 68.1 & 10.4 \\
\hline 26109 & South sido of Redfish Bay.... & 6 feet below bed of sea......... & .0 & .0 & .2 & .2 & 9.6 & 63.2 & 26.6 \\
\hline 26200 & Pilottown wharf............ & 10 to $10 \frac{1}{2}$ feet below surface...... & .0 & .0 & .1 & .4 & 42.4 & 51.7 & 5.1 \\
\hline 20201 & 2 miles west of Burrwood....... & $2 f$ feet below water surface........ & .0 & .2 & .1 & .6 & 22.0 & 58.6 & 18.6 \\
\hline 26202 & $\begin{array}{l}\text { Point of land where South } \\
\text { Pass and Southwest Pass } \\
\text { soparate. }\end{array}$ & 12 feet below surface.......... & .0 & .0 & $\cdot .1$ & 2.3 & 8.1 & 66.8 & 22.6 \\
\hline 26203 & Mud lump near Pass a Loutre. & 9 feet below surface of mud lump. & .2 & .3 & .2 & 1.5 & .6 & 39.2 & 58.0 \\
\hline 20204 & 200 fcot from river, Port Eads. & 11 feet below surface.............. & .0 & .1 & .1 & 2.5 & 36.9 & 51.8 & 8.7 \\
\hline 26205 & Mouth of Mississippi River.... & Composite made up of $235 \mathrm{sam}-$ & .3 & .5 . & .2 & 6.5 & 28.2 & 51.2 & 13.0 \\
\hline & & Passes. & & & & & & & \\
\hline & \multicolumn{2}{|c|}{$\Lambda$ vernge of all analyses except No. $26205 \ldots \ldots \ldots \ldots$} & .005 & .12 & .14 & 2.17 & 23.38 & 52.65 & 21.39 \\
\hline
\end{tabular}

The most important and impressive part of the above table is the analysis of sample No. 26205, which shows that fine gravel, coarse sand, and medium sand are present in the upper part of the Delta, though only in minute quantity. Fine sand makes up about one-fifteenth of the material and very fine sand a little over one-fourth. The great bulk of the material is silt, over one-half of all the particles measuring between 0.05 and 0.005 millimeter, or about 0.002-0.0002 inch. Even clay is present in the subordinate amount of 13 per cent, or a little more than one-eighth.

The chemical character of the material lying near the surface in the vicinity of the mouths of the river is shown in the following table giving a preliminary report of an analysis of the cornposite sample numbered 26205 in the above table, which is being made by George Steiger in the chemical laboratory of the United States Geological Survey, and also analyses of mudlump clay and of river-borne sediment, made by Walter N. Howell. 
Chemical analyses of air-dried samples of material from upper part of Mississippi Delta.

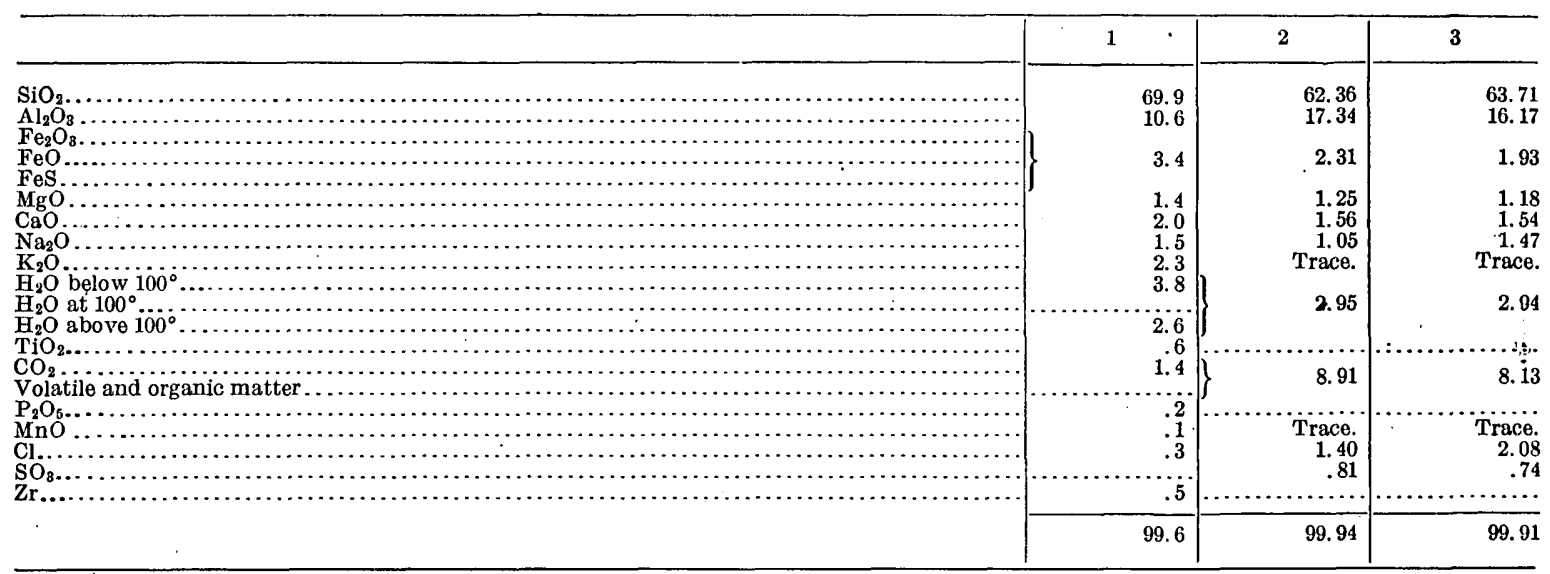

1. Composite made up of 235 samples collected by E. W. Shaw within 45 feet of surface in marshes and shallow water below Head of Passes, most of the material from the upper 20 feet of the Delta. George Steiger, analyst.

2. Sample of mud-lump clay from near Burrwood.

In order to determine the character and arrangement of the material in the Delta, a sampling rod was used for getting samples beneath the surface, the rod being pushed down to the place where it was desired to take the sample. The various degrees of resistance of the sands and clays, or rather sandy silt and clayey silt, were thus readily noted. The "quicksand" of the Delta is not so quick or fluid as the clay. The sampler passes very easily through beds of clayey silt but can be forced only with difficulty through layers containing a considerable amount of sand, and often the sand prevents it from reaching a depth of 20 feet. The sand is so much more resistant than the clay that piles sunk in New Orleans for the larger buildings are driven down through clay and silt to a comparatively thick bed of sand that lies 60 to 80 feet below the surface and serves as a firm foundation.

It appears that the most rigid material in the Delta is a mixture of sand and clay in certain definite proportions. Crusty layers "as hard as asphalt" are sometimes reported, and it seems probable that such layers do not consist of iron oxide or other uncommon material but of a sand-clay mixture, and that there is every stage of gradation between this unusually resistant material and the very fluid clays. Experiments are now being made with mixtures of sand and clay which it is hoped will furnish further information on this subject.

The total thickness of the material properly referable to the Mississippi Delta is not definitely known but is probably at least 2,000 feet. The shape of the rock basin on which this material rests is also unknown; its sides may be concave or convex, and some think that it is traversed by a large central trench. Several wells have been sunk 2,000 feet or more into this Delta material, and although logs of some of them have been kept and fossils preserved, the identification of the beds is still uncertain. An unusually large amount of data seems to be needed to determine positively the age of these strata.

The general character of the Delta material down to a depth of about 1,000 feet is illustrated by the record of a well drilled in $\mathbf{1 8 9 5}$ on the Magnolia sugar plantation, on the west bank of Mississippi River, about 45 miles below New Orleans. The well is owned by ex-Gov. H. C. Warmoth, who furnishes the following record:

Record of well on Magnolia sugar plantation.

\begin{tabular}{|c|c|c|}
\hline & Thickness. & Depth. \\
\hline 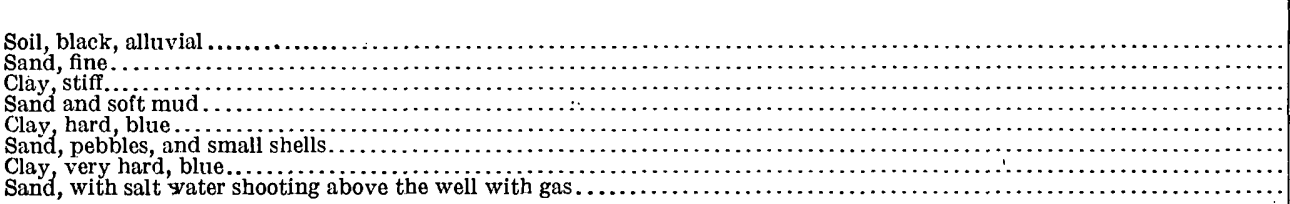 & $\begin{array}{r}\text { Feet. } \\
40 \\
30 \\
50 \\
40 \\
200 \\
210 \\
377 \\
33\end{array}$ & $\begin{array}{r}\text { Feet. } \\
40 \\
70 \\
120 \\
160 \\
360 \\
570 \\
947 \\
980\end{array}$ \\
\hline
\end{tabular}


Silt is accumulating just offshore at the rate of several inches a year, as may be shown by taking a profile of the ocean, bottom adjacent to the mouths of the river and drawing a parallel line to correspond to the estimated annual seaward advance, about 300 feet. (See figs. 3 and 4.) The character of the material deposited appears to vary from season to season. During the period of high water, which generally includes the first half of the calendar year, the sediment is noticeably coarser than during the period of low water, which includes roughly the second half of the year. The apparent result is a structure somewhat resembling the annual rings of growth of trees. As the sampling rod is forced into the earth it moves downward easily for a few inches, and then with difficulty for a few inches, and so on, in alternation. The minuteness and legibility of the record remain to be determined, but the principal floods and the principal times of drought are probably recorded.

The material collected by the Fish Hawk expedition from the bottom of the Gulf off the mouth of the Mississippi also indicates that the deposits consist in general of alternating layers
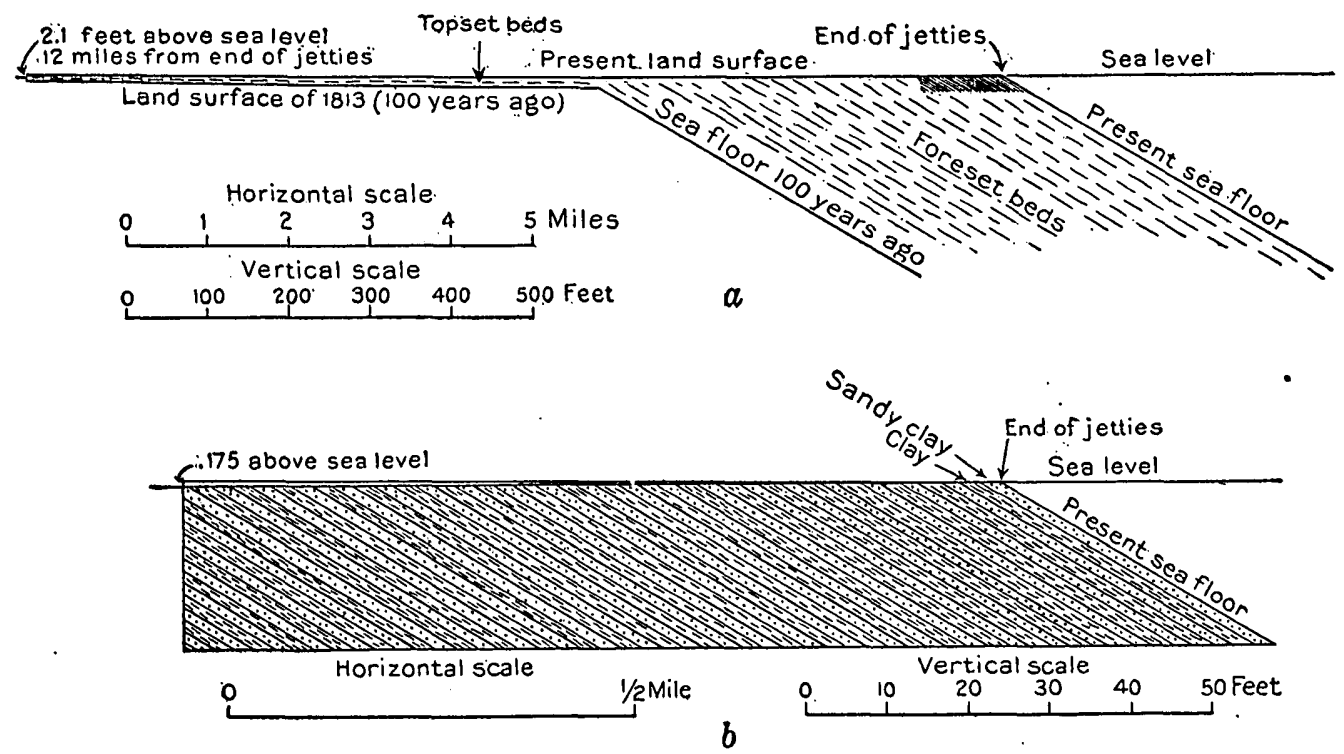

Fiqure 3.-Profles showing present and past land surface and sea bottom near mouths of Mississippi. a, Generalized profile of present land surface and sea bottom from the Head of the Passes to a point 4 miles beyond end of South Pass jetties and also of position of corresponding surface 100 years ago. Shows the great thickness of the foreset beds of the Delta as compared with that of the topset beds, which apparently would be only about one-tenth as thick as they are if they were not affected by subsidence. In order to show the topset beds at all it is necessary to exaggerate grossly the vertical scale. $b$, Enlarged section of the foreset beds represented by the finely ruled portion of $a$, showing annual and seasonal growth layers. The estimated advance of the bars at the mouths of the Passes of 340 feet a year is believed to be considerably greater than the average rate at which the land is pushing out to sea. The above diagrams represent an annual advance of 265 fout, which is possibly too large.

of sandy and clayey silt. The dredges brought up from the bottom a mixture of dark clay and light gray sandy slime, the two apparently coming from different layers. The core samples consist uniformly of stratified material with stiff clay or sandy clay at the bottom and beds of increasing fluidity to the top, which is nearly clear water. The most compact material was found near the ends of the Passes in less than 5 fathoms of water.

\section{PROCESSES AND CONDITIONS AFFECTING MODE OF GROWTH.}

Certain features of the Delta suggest that it is affected by a process which heretofore seems not to have been suspected, namely, a bodily flowage toward the sea. The surface receives a new layer of sediment at each flood, but its altitude above sea does not seem to show a corresponding increase. Timbers and other objects left on the surface appear to sink down into the earth, and on careful examination it becomes evident that the Delta is sinking as well as building upward and outward, the coast being most affected. The tide gage records at Port Eads show a gradual increase in the apparent height of mean tide from 2 feet 20 years ago to 4 feet now; $12023^{\circ}-13-2$ 
in other words, that part of the Delta is sinking at a rate of a tenth of a foot a year. The shape of the sea bottom just offshore suggests local bulging of the Delta front, for it is characterized by irregular swells and hollows which change from time to time in form and position and by an

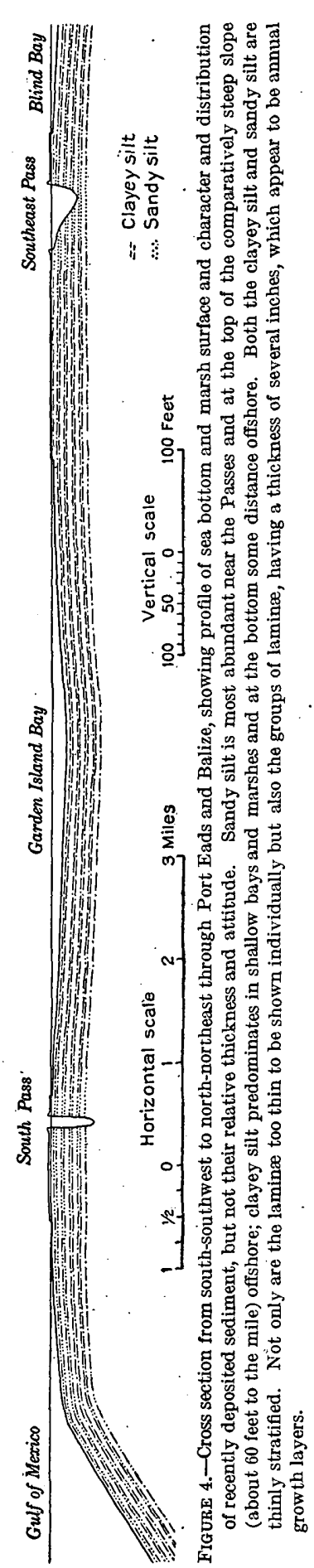
absence of well defined channels. In 1905 and 1907 shoaling was reported fully 25 miles southeast of Port Eads, depths of only 65 to 100 fathoms being found where before the depth was 300 to 600 fathoms. The character of the coast itself in places where sedimentation is not now rapid strongly suggests subsidence, especially the coast near Barataria Bay and on Breton and Chandeleur sounds. In these areas the boundary between land and sea is intricately irregular, small islands rise just above the sea, and shallow lakes and bays are abundant. The shore features seem to be just those which would result from gentle subsidence of a.low-lying, slightly uneven surface. The sinking is due in part, no doubt, or perhaps entirely, to the compacting of the sediment. Whatever its exact nature, the facts that the subsidence is greatest where the Delta is growing most rapidly and that because of the very watery condition of the material it is presumably becoming more compact make it seem probable that the process is only in part, if at all, one of isostatic adjustment. At a depth of 5,000 feet there may be no downward movement.

However, certain facts suggest that in comparatively late geologic time this region has been affected by crustal deformation. Deposits which outcrop in a district farther north and which have been described as the Lafayette formation, the loess, and the Port Hudson clay have been thought to indicate general elevation and subsidence, and in the vicinity of New Orleans, at least, coarse sand evidently deposited in shallow water occurs at various depths down to 3,000 feet, but in addition differential uplift appears to have occurred in the vicinity of Natchez. Otherwise the gravel, which contains pebbles brought apparently from Canada and lies as much as 200 feet above the present stream, calls for an extremely low gradient upstream and an almost impossibly high gradient downstream. The narrowness of the flood plain at Natchez and the outline of the area less than 100 feet above sea level, this area being considerably broader above than opposite Natchez, suggest the same conclusion.

In this connection it is interesting to note that in the recent determinations of intensity of gravity made by the Coast and Geodetic Survey the earth near New Orleans was found not to have an excess of mass, as might be expected from the vast amount of sediment which has accumulated there, but a deficiency equivalent to a lack of about 430 feet of strata. In other words, if the surface at New Orleans were buried under 430 feet of solid rock, the district would then be in approximate balance with the rest of the world.

Below Baton Rouge the river flows southeastward and the great body of the delta has developed in that direction. It is only about a third as far from Baton Rouge to the sea in a southwesterly direction as it is in a straight line to the mouths of the river. The reason for this trend may be that a westward littoral current tends to throw the sediment in that direction from the mouths of the river and in this way to crowd the outlet eastward, but the known facts do not appear sufficient to warrant a definite conclusion.

The protruding character of the coast at the mouth of the river is a somewhat striking testimony against the idea that subsidence always produces deep bays. The form of a coast 
depends on many factors-sedimentation, erosion, deformation, and the nature and extent of the work done in previous cycles.

Filgard has pointed out that the Mississippi Delta differs markedly from other deitas, and also from an ideal delta. He says: ${ }^{a}$

. The bird-foot shape of the lower Mississippi Delta, with deep embayments in between, is unexampled in any other large river delta in the world. The bays between the delta fingers ("passes") are being very slowly shallowed, chiefly by wave and tidal action from the Gulf carrying in the bar sands, and only subordinately by river overflow. The river in. this lower delta region is for 50 miles below Fort Jackson bordered by narrow banks of unyielding gray clay, between which is carried the entire volume of the river through the narrow-banked "neck" until it reaches a common point of divergence, the Flead of the Passes, whence similarly narrow-banked channels diverge, unbranched, in birdfoot form.

The usual shape of a normal delta is a convex protrusion beyond the main shore line, with usually slight protrusions at the mouths of the distributaries, as can be seen by an inspection of the maps of the deltas of any of the larger rivers, such as the Nile, Ganges, Brahmaputra, Danube, Volga, Lena, and others. Within the delta areas of these streams large and small distributaries form a complex network, frequently changing at times of high water. No such changes are shown by the narrow-banked, diverging arms of the lower Mississippi Delta, which steadily advance into the Gulf singly, and without any permanent distributaries being formed. The only approach to the form and structure of an ordinary delta occurs about 3 miles above the Flead of the Passes, on the east side, where small and shallow channels connect with the main river through Cubit Gap, a shallow lateral outlet.

The typical delta developments at Cubit Gap, at the Jump, and in Garden Island Bay, not yet represented on charts, have resulted from unusual conditions-accidents, so to speakin the course of delta development. The full history of the land development-at the Jump is not known, but in the other two places, and probably at all three, the river has broken through narrow banks which separated it from the sea, and very rapid sedimentation has followed. The astounding fact in this connection is that the river does not more frequently cut through its narrow banks, although it of ten overflowed these banks before the levees were built, during a time when the present features were developing. At Bird Island Sound the river might reach sea level in a quarter of a mile, but instead it takes a course of about 25 miles. Just below New Orleans the river might reach sea level by flowing eastward less than 10 miles through territory subject to overflow, but instead it flows fully 100 miles southwestward. Hilgard believes that these remarkable features are due to "a compact, impervious gray clay, corresponding exactly to the material constituting the mud lumps," clay which "so long as it remains submerged or fully wetted * * * resists erosion to a remarkable degree." To the present writer, however, this inference does not seem well founded. The exposures and borings along the river banks show a large proportion of fine sand, which is easily washed. Several borings were made at and near the Head of the Passes to test this point and sand was found in all of them. (See the mechanical analysis of sample No. 26202.) Clay is present in places and may possibly be the remains of old mud lumps, but a large part of the material appears to be incoherent sand. To-dry the coarsest sediment is being deposited on or near the river banks, where it accumulates to such an extent as to form natural levees that border the river almost if not quite to the sen, and just offshore in the immediate vicinity of the ends of the passes. The finer particles are carried by the river water in times of overflow into the marshes at some distance from the river and by the sea water at all times into the bays between the passes and to a large surrounding area of deep water lying at a distance greater than 2 or 3 miles from the river mouths. As indicated in figure 4, the sandiest material found in the borings lay near the river banks and the most clayey material in the marshes several miles from the river.

All the movements of the sea water at the mouths tend to sort out the finest sediment there discharged and carry it to distances depending in part on the size of the particles. In a few places, particularly in the most exposed positions, as at the outermost ends of the passes and 
also where the sediment is accumulating slowly, as in Bird Island Sound, this process goes so far as to develop sand beaches. The very fine material consists not only of the finest solid particles, brought down in that form by the river, but also of matter transported in a colloidal form and fiocculated by the salt of the sea, and it is commonly apparent in the water 10 miles or more from land. At times and in places the line between the muddy and the clear water is very sharp, as shown in Plate I, $B$.

Thus it seems to the writer, both from field evidence and from indirect theoretical considerations, that the river banks consist not of clay which, though yielding to pressure, is so resistant to corrasion that it determines the location of the river channels, but of sand which is resistant to pressure and yielding to water currents, with perhaps some mud-lump clay here and there. It seems probable that the form of the river here, as elsewhere throughout its course below Cairo, must be produced in detail by a balance among the hydraulic forces involved in the river flow; that the stream is so large and powerful that no clay could long prevent it from cutting just such a channel as a balance among its forces demands. Yet this must be regarded only as a suggestion, for although much is known concerning the hydraulics of river flow many phenomena are not yet fully understood. For example, above Baton Rouge the river is broad and very shallow, carries much coarse sand, and has a tendency tó meander which seems beyond human power to control, whereas below that city it is little more than half as broad, is 100 to 200 feet deep, has little tendency to meander, and seems adjusted to its load of very fine sand and silt and quite competent to carry it. To the writer it seems probable that the peculiar form of the river near its mouths is related in cause to these phenomena.

The offshore movement of the river water is indicated by the following analyses of samples, most of which were collected on the Fish Hawk expedition. The samples that show the largest amount of chlorine are, of course, those that contain the least river water. The regularly greater chlorine content of the bottom samples accords with the conditions elsewhere and is due to the fact that river water, having less density than sea water, flows out at the surface of the sea. The table includes also analyses of a few samples of sludge from springs on mud lumps.

The examinations of chlorine in this table were made by E. C. Bain, under the direction of R. B. Dole. The tests were made by means of a salinity outfit supplied by the Copenhagen laboratory of the Conseil Permanent International de la Mer; which was obtained through the courtesy of the United States Bureau of Fisheries. The procedure is an adaptation of the usual method of estimating chlorine by titrating with silver nitrate in presence of potassium chromate. An essential feature is a sealed tube of standard sea water whose content of chlorine has been very carefully determined. This water is used for comparison, and the pieces of the apparatus are so constructed and calibrated as to insure maximum accuracy. Standard sea water No. $\mathrm{P}_{7} 2 / 2,1912$, with a chlorine content of 19.386 grams per kilogram, was used, but as only a little of it was available, a large sample of nearly normal sea water was very carefully titrated and used for frequent comparison during the tests. Float burette No. 8, measuring about 1.5 millimeters between gradations, and pipette No. 3 , having a capacity of 15.04 cubic centimeters, were used. 
Tuble showing chlorine content, 'specific gravity, temperature, and other data concerning water samples collected near mouths of Mississippi River.

['The measurements of specific gravity are only approximate and subject to a correction of \pm 0.002 , the average error being probably not over 0.0005 ; distances are given in statute miles and bearings are true; samples were collected on June 22, 23, 24, and 25, 1913.]

\begin{tabular}{|c|c|c|c|c|c|c|}
\hline $\begin{array}{l}\text { Station } \\
\text { No. }\end{array}$ & Location. & $\begin{array}{l}\text { Depth of } \\
\text { water } \\
\text { (feet). }\end{array}$ & $\begin{array}{l}\text { Position of } \\
\text { water. }\end{array}$ & $\begin{array}{l}\text { Chlorine } \\
\text { (grams per } \\
\text { kilogram). }\end{array}$ & $\begin{array}{l}\text { Tempera- } \\
\text { ture }\left({ }^{\circ} \mathrm{F} .\right)\end{array}$ & $\begin{array}{l}\text { Specific } \\
\text { gravity. }\end{array}$ \\
\hline 7900 & 84 miles from Galveston and 29 miles S. $51^{\circ} \mathrm{E}$. of Sabine Bank light..... & 57 & & $\begin{array}{l}13.60 \\
18.73\end{array}$ & 80 & \\
\hline 7001 & $\left\{\begin{array}{l}11 \text { miles S. } 74^{\circ} \text { E. of Trinity Shoal buoy, about midway between } \\
\text { Galvestion and Southwest Pass. }\end{array}\right.$ & 48 & $\left\{\begin{array}{l}\text { Surface... } \\
\text { Bottom.. }\end{array}\right.$ & $\begin{array}{l}15.76 \\
17.22\end{array}$ & $\begin{array}{l}80 \\
79\end{array}$ & \\
\hline 7902 & 35 miles S. $71^{\circ} \mathrm{E}$. of Trinity Shoal buoy $\ldots \ldots \ldots \ldots \ldots \ldots \ldots \ldots \ldots \ldots \ldots \ldots \ldots \ldots \ldots \ldots$ & 63 & $\left\{\begin{array}{l}\text { Surface... } \\
\text { Bottom. }\end{array}\right.$ & $\begin{array}{l}16.90 \\
17.64\end{array}$ & $\begin{array}{l}80 \\
791\end{array}$ & $\begin{array}{l}1.019 \\
1.0205\end{array}$ \\
\hline 7803 & $\left\{\begin{array}{l}20 \text { miles S. } 42^{\circ} \mathrm{E} \text {. of Timbalier Island light, nearly } 50 \text { miles west of } \\
\text { Southwest Poss. }\end{array}\right.$ & 102 & $\left\{\begin{array}{l}\text { Surface... } \\
\text { Bottom. }\end{array}\right.$ & $\begin{array}{l}13.42 \\
19.91\end{array}$ & $\begin{array}{l}82 \\
74\end{array}$ & $\begin{array}{l}1.015 \\
1.02425\end{array}$ \\
\hline $\begin{array}{l}7903.1 \\
7903.2\end{array}$ & 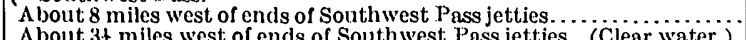 & & Surface.. & 13. 65 & & a....... \\
\hline $\begin{array}{l}7903.2 \\
7903.4\end{array}$ & $\begin{array}{l}\text { A bout } 3 \mathrm{f} \text { miles west of ends of Southwest Pass jetties. (Clear water.). } \\
\text { About } 3 \text { miles west of ends of Southwest Pass jetties. (Yellowish } \\
\text { muddy water.) }\end{array}$ & & $\begin{array}{l}\text { Surface.. } \\
\text { Surface.. }\end{array}$ & $\begin{array}{r}15.62 \\
5.08\end{array}$ & & $\cdots \cdots \cdot$ \\
\hline 7904 & 1t miles S. $11^{\circ} \mathrm{W}$. of light on east jetty of Southwest Pass.............. & 72 & $\left\{\begin{array}{l}\text { Surface } a \\
\text { Bottom.. }\end{array}\right.$ & 8.63 & $80 \frac{1}{2}$ & 1.0095 \\
\hline 7905 & 3 miles S. $45^{\circ}$ E. of lightship just outsicle of Southwest Pass. . & 228 & $\left\{\begin{array}{l}\text { Surface. } \\
\text { Bottom. }\end{array}\right.$ & $\begin{array}{r}2.11 \\
17.79\end{array}$ & 81 & .998 \\
\hline 7906 & 7f miles S. $33^{\circ}$ E. of lightship just outside of Southwest Pass......... & 357 & $\left\{\begin{array}{l}\text { Surfac } \\
\text { Botto }\end{array}\right.$ & $\begin{array}{l}12.64 \\
19.28\end{array}$ & $827^{2}$ & $\begin{array}{l}1.013 \\
1.0235\end{array}$ \\
\hline 7007 & $7 \$$ miles S. $17^{\circ}$ E. of station $7906 \ldots \ldots \ldots \ldots \ldots \ldots \ldots \ldots \ldots \ldots \ldots \ldots$ & 585 & $\left\{\begin{array}{l}\text { Surface.. } \\
\text { Bottom. }\end{array}\right.$ & $\begin{array}{l}14.46 \\
19.05\end{array}$ & 82 & $\begin{array}{l}1.015 \\
1.022\end{array}$ \\
\hline 7008 & 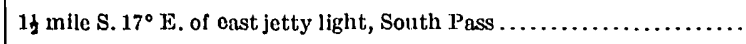 & 102 & $\left\{\begin{array}{l}\text { Surface... } \\
\text { Bottom. }\end{array}\right.$ & 5.86 & $82 \frac{1}{2}$ & $\begin{array}{l}1.00525 \\
\ldots \ldots . .\end{array}$ \\
\hline $7008 \mathbf{a}$ & $\begin{array}{l}\text { About } 600 \text { feet below surface of sea and about } 18 \text { miles S. } 16^{\circ} \mathrm{W} \text {. of } \\
\text { South Pass light. }\end{array}$ & & & 19.99 & & \\
\hline $7008 \mathrm{~b}$ & 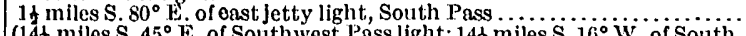 & & Surface. & .36 & & \\
\hline 7009 & $\left\{\begin{array}{c}14 \frac{1}{1} \text { miles S. } 45^{\circ} \mathrm{E} \text {. of Southwest Pass light; } 14 \frac{1}{2} \text { miles S. } 16^{\circ} \mathrm{W} \text {. of South } \\
\text { Pass light. }\end{array}\right.$ & 456 & $\left\{\begin{array}{l}\text { Surface... } \\
\text { Bottom. }\end{array}\right.$ & $\begin{array}{l}13.88 \\
19.85\end{array}$ & $\begin{array}{l}81 \\
71\end{array}$ & $\begin{array}{l}1.015 \\
1.0235\end{array}$ \\
\hline 7010 & 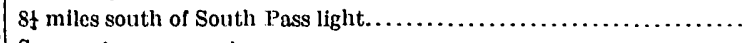 & 306 & $\left\{\begin{array}{l}\text { Surf } \\
\text { Bot }\end{array}\right.$ & $\begin{array}{r}7.42 \\
17.12\end{array}$ & $\begin{array}{l}79 \\
69\end{array}$ & $\begin{array}{l}1.00825 \\
1.021\end{array}$ \\
\hline 7010 & Samo, plunger sample ................. & 306 & Bottom. & 19.81 & & \\
\hline 7011 & 6t miles S. $45^{\circ}$ E. of South Pass light..... & 252 & $\left\{\begin{array}{l}\text { Surface... } \\
\text { Bottom }\end{array}\right.$ & $\begin{array}{r}9.15 \\
19.69\end{array}$ & $\begin{array}{l}80 \\
64 \frac{1}{2}\end{array}$ & $\begin{array}{l}1.010 \\
1.0235\end{array}$ \\
\hline 7911 & Snme, plunger sample ..................... & 252 & Bottom. & 19.53 & & \\
\hline 7912 & 07 miles S. $50^{\circ}$ E. of South Pass light........ & 336 & $\left\{\begin{array}{l}\text { Surlace. } \\
\text { Bottom. }\end{array}\right.$ & $\begin{array}{l}13.62 \\
19.97\end{array}$ & $\begin{array}{l}81 \\
66 \frac{1}{2}\end{array}$ & $\begin{array}{l}1.0135 \\
1.023\end{array}$ \\
\hline 7913 & $12 \frac{1}{2}$ miles S. $51^{\circ}$ E. of South Pass light...... & 732 & $\left\{\begin{array}{l}\text { Surface.. } \\
\text { Bottom. }\end{array}\right.$ & $\begin{array}{l}14.16 \\
19.82\end{array}$ & 81 & $\begin{array}{l}1.014 \\
1.024\end{array}$ \\
\hline 7914 & 10 miles S. $82^{\circ}$ E. of South Pass light.... & 288 & $\left\{\begin{array}{l}\text { Surface... } \\
\text { Bottom. }\end{array}\right.$ & $\begin{array}{l}10.60 \\
18.47\end{array}$ & $\begin{array}{l}82 \\
76 \frac{1}{2}\end{array}$ & $\begin{array}{l}1.0115 \\
1.0225\end{array}$ \\
\hline 7915 & 10 miles N. $78^{\circ}$ E. of South Pass light........... & 204 & $\left\{\begin{array}{l}\text { Surface.. } \\
\text { Bottom. }\end{array}\right.$ & $\begin{array}{r}6.71 \\
19.27\end{array}$ & 83 & $\begin{array}{l}1.006 \\
1.023\end{array}$ \\
\hline 7016 & 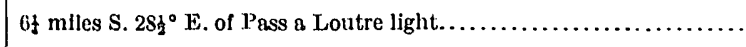 & 72 & $\left\{\begin{array}{l}\text { Surface.. } \\
\text { Bottom. }\end{array}\right.$ & $\begin{array}{l}2.66 \\
6.24\end{array}$ & $84 \frac{1}{2}$ & $\begin{array}{l}1.000 \\
1.00625\end{array}$ \\
\hline 7917 & 5 miles S. $30^{\circ}$ E. of Pass a Loutre light........ & 16 & $\left\{\begin{array}{l}\text { Surface. } \\
\text { Bottom. }\end{array}\right.$ & $\begin{array}{r}1.65 \\
10.70\end{array}$ & $\begin{array}{l}85 \\
78\end{array}$ & $\begin{array}{r}.9985 \\
1.0125\end{array}$ \\
\hline 7918 & $7 \frac{1}{2}$ miles S $47^{\circ} \mathrm{E}$. of Pass a Loutre light.... & 126 & $\left\{\begin{array}{l}\text { Surface.. } \\
\text { Bottom. }\end{array}\right.$ & $\begin{array}{l}2.67 \\
2.62\end{array}$ & $\begin{array}{l}86 \\
68\end{array}$ & $\begin{array}{l}1.000 \\
1.000\end{array}$ \\
\hline 7910 & $11_{1}$ miles S. $51^{\circ}$ E. of Pass a Loutre light... & 330 & $\left\{\begin{array}{l}\text { Surface.. } \\
\text { Bottom. }\end{array}\right.$ & $\begin{array}{r}9.01 \\
19.79\end{array}$ & $\begin{array}{l}83 \\
64\end{array}$ & $\begin{array}{l}1.00925 \\
1.02425\end{array}$ \\
\hline 7018 & Sßmo, plunger sample................... & 330 & & 19.83 & & \\
\hline 7020 & $5 \frac{1}{2}$ miles S. $56^{\circ}$ E. of station $7919 \ldots \ldots \ldots$ & 486 & $\left\{\begin{array}{l}\text { Surface. } \\
\text { Bottom. }\end{array}\right.$ & $\begin{array}{l}12.79 \\
18.14\end{array}$ & $\begin{array}{l}82 \frac{1}{2} \\
74\end{array}$ & $\begin{array}{l}1.013 \\
1.021\end{array}$ \\
\hline 7021 & 40 miles N. $39^{\circ}$ E. of station $7917 \ldots$ & 102 & $\left\{\begin{array}{l}\text { Surface.. } \\
\text { Bottom. }\end{array}\right.$ & $\begin{array}{l}13.52 \\
17.08\end{array}$ & $82 \frac{1}{2}$ & $\begin{array}{l}1.014 \\
1.022\end{array}$ \\
\hline
\end{tabular}

a Strong odor of hydrogen sulphide. Gas driven off by boiling before determination of chlorine.

Chlorine content of additional samples, in grams per kilogram of water.

Surface sea water in West Bay + mile north of first lump north of Bald Lump, 1 mile west of Burrwood, La.;

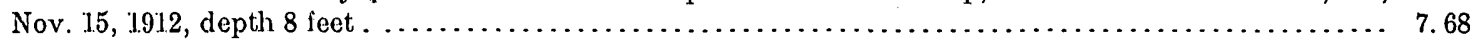

Black mud spring on minor Cactus lump, Burrwood, La., 1 foot below surface of water; Nov. 16, 1912 ...... 15.99

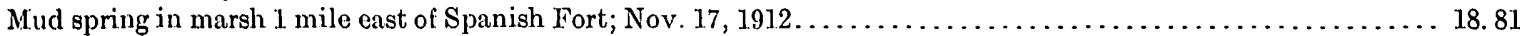

Sludge from mud spring on fourth right mud lump off Pass a Loutre (Mud Spring special No. 3); Nov. 20, 1912 ... 17. 18

The following data may be used for comparison:

Chlorine, in grams per kilogram, contained in water taken from different places.

Average for Mississippi River at New Orleans for 1905-6. (Analyses by J. L. Porter, chemist, New Orleans

Water and Sewerage Board, U. S. Geol. Survey Water-Supply Paper 236, p. 77, 1905)............. 0.0097

Sen water from southwest channel! Tortugas, Fla. (Sample collected in May, 1912, and tested at the

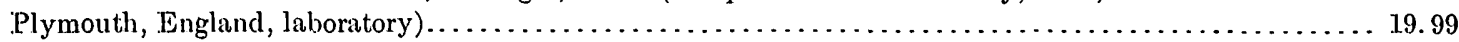

Average of 52 samples collected in May and June, 1913, from southwest channel, Tortugas, Fla. (Deter-

minations made by R. B. Dole, U. S. Geological Survey) ................................ 19.95

Avernge content of normal sea water. (Standard sea water, $\mathrm{P}_{7} 2 / 2,1912$, issued by the Conseil Permanent

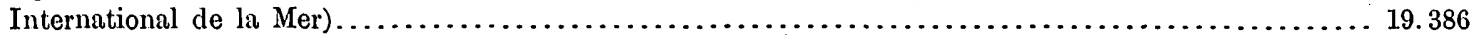


The principal processes affecting the lower end of the Delta may be summarized briefly. The most important is the building out of the coast line through the accumulation of sediment brought down by the river, the rate of progradation varying from season to season. Throughout the lower part of the river's course it tenids to build natural levees-that is, to make the land near the river higher than that at a distance-and this tendency or a stiff clay or some other factor has caused the delta to assume a bird-foot form. Littoral currents and practically all other movements of the sea water tend to spread and sort the sediment. These movements vary greatly from time to time and the method and extent of the distribution of sediment are unknown, though probably more sediment goes westward than eastward. The beating of the waves, though much less severe than in many other regions, produces some modifications of the shore line. General subsidence, perhaps brought about by simple compacting and perhaps by bodily flowage, allows the sea to encroach on the land where sedimentation is not most active. Plants advance seaward by groups and check the transportation of sediment in the areas of which they take possession. Lastly, there is this strange growth of mud lumps, which plays an important part in arranging the material within the delta and perhaps also, as Hilgard thinks, in locating and permanently confining the river channels.

\section{THE MUD LUMPS.}

The mud lumps generally lie within a mile of the end of a pass, no pass being entirely free from them, and are most numerous on the right side of each channel. One is now active 1 mile south of the old Spanish magazine, 2 miles north of the mouth of Balize Bayou, and perhaps its development is due to the fact that this bayou has recently become much enlarged. A few others have been reported at somewhat greater distances from the end of a pass, but most of them cluster rather closely about the outlets of the river. Just now they are most numerous south of the end of Pass a Loutre, a chain of 20 or 30 lumps having developed in this district in the last few years. North, Northeast, and Southeast passes each contain a few. South Pass contains four or five, and Southwest Pass about a dozen.

The lumps are commonly 20 or 30 rods broad and stand 20 or 30 feet above the adjacent bottom. With reference to sea level their heights are somewhat closely concordant, few extending more than 8 or less than 2 feet above the water. They are rounded or elliptical at first but their exposed portions are soon carved into irregular shapes and some are cut in two by wave action. Their growth occupies from a few hours to several years and is usually irregular. Generally a mud lump rises in a few weeks or months to a height of 4 or 5 feet above the surface of the water. Then it remains quiescent and is beaten down by the waves in the course of a few years. Many of them subside, however, and some have disappeared in a night. Those that rise slowly are considerably worn before they stop growing. Those that rise more rapidly and in protected places are capped by laminated silt having a maximum thickness of 10 feet. The lumps are appreciably more active during and immediately after high water. This is well shown in figure 5 . Concerning the date given in this figure Mr. J. L. Hortenstine, of the United States Corps of Engineers, says in a letter:

There was dẹposited in this area a total of $2,500,000$ cubic yards of material during the recent high stage of the river. This material was deposited during the months of March, April, and May, 1913. The additional material caused an increased pressure over the area of 1,800,000 tons, or a mean pressure of 400 pounds per square foot. The maximum pressure is found at a distance of 600 feet upstream from the chain of mud lumps shown on chart No. 5 [fig. 5,a] and this pressure is approximately 825 pounds per square foot.

The stories related by sailors and pilots concerning the mode of growth of the mud lumps are fairly consistent. One man states that the growth of a mud lump was accompanied by a rather loud roar as it rose above the water, and another states that he once saw flashes of light rising from a mud lump, but these statements are very different from the great mass of testimony concerning the lumps, and it seems probable that they are not based on fact. 

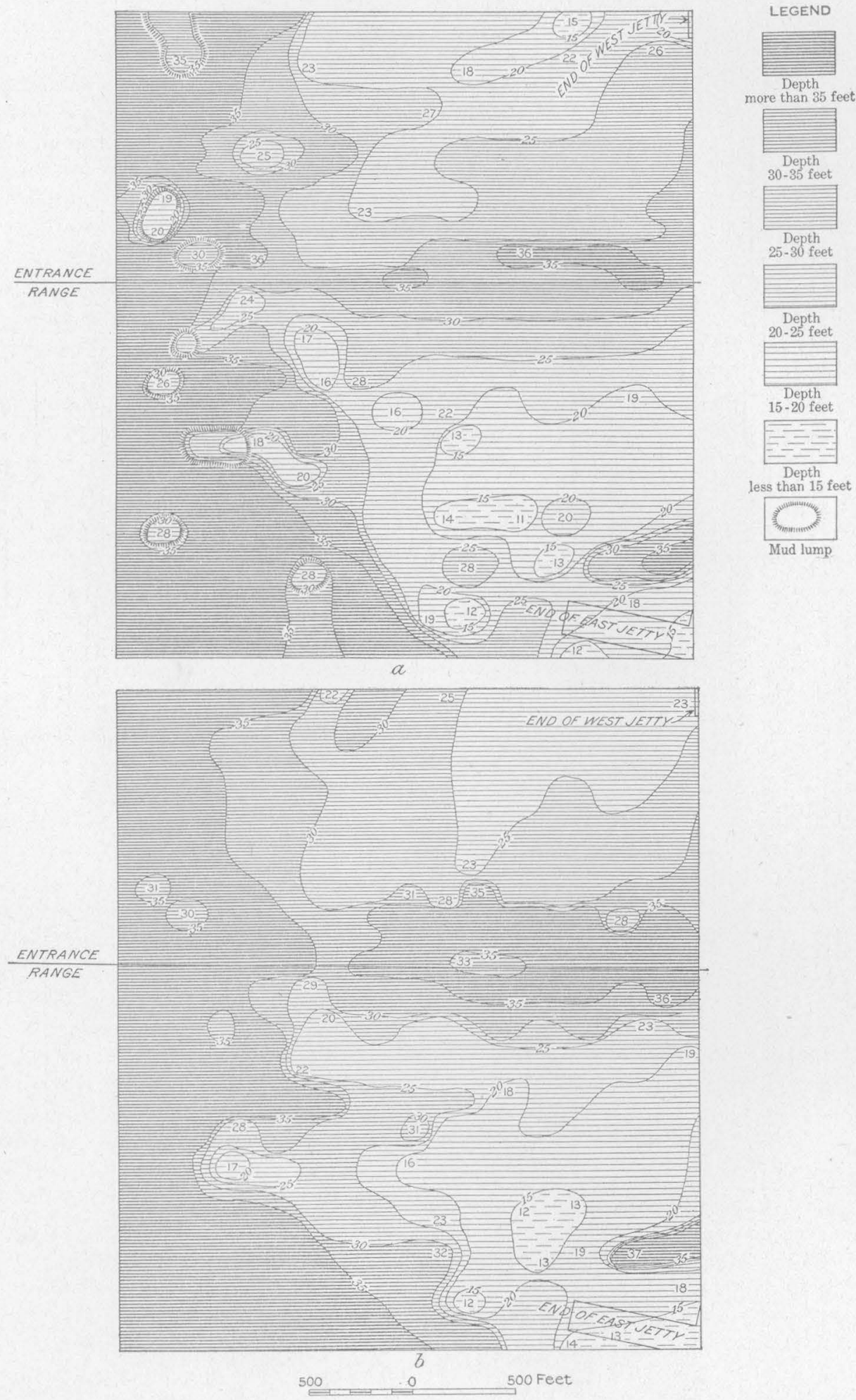

Figure 5.-Two charts of the entrance to Southwest Pass. $a$, Chart showing activity of mud lumps from May 20 to June 6 , 1913 , at the elose of a high-water period; $b$, Chart showing mud-1ump quiescence from August 1 to 13,1913 , during a low-water period, when the apparent absence of lumps is due to subsidence (perhaps through movement elsewhere and perhaps through the removal of the surplus load of water) or to cutting away by degrees and to filling in the hollows between with sediment. From data furnished by United States Corps of Engineers. 
The structure of the mud lumps appears to be comparable to that of bysmaliths. (See fig. 6.) A dark bluish-gray clay of medium stiffness and great stickiness forms the central core. As shown in the analysis of sample No. 26203, this clay contains some sand and silt, though not in amounts sufficiently large to affect its consistency perceptibly. Upon and around the clay core lies a series of faulted and folded strata of sand and silt which have been carried up from

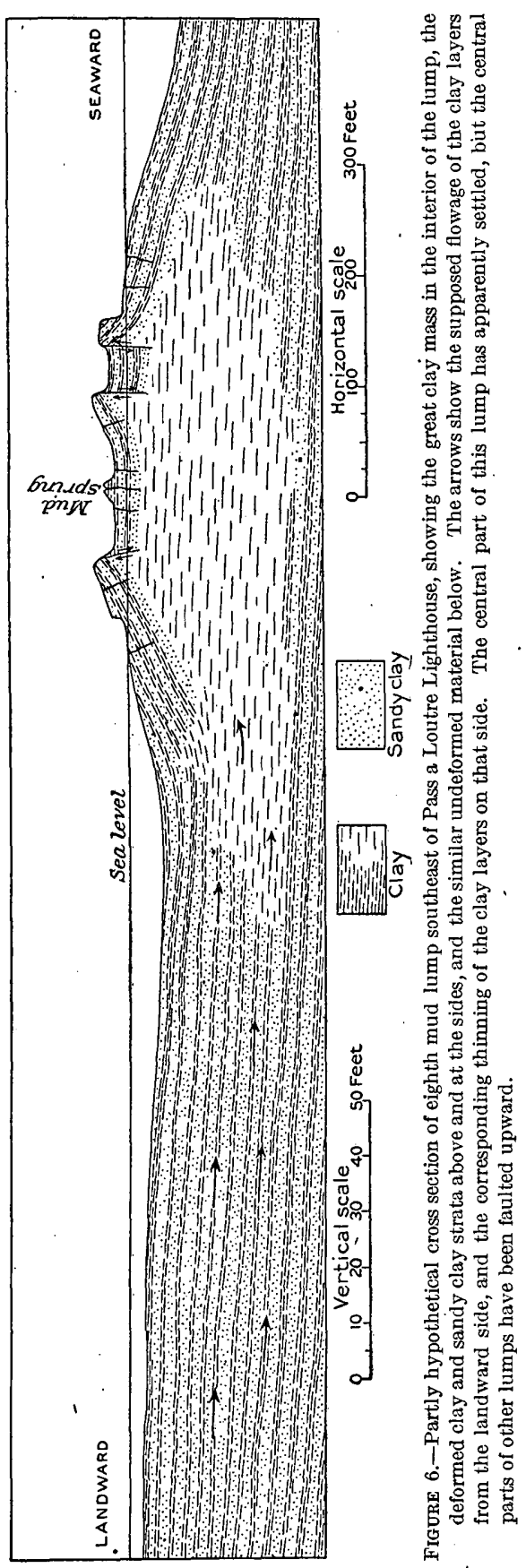
the sea bottom and deformed in the upheaval. The upper parts of the mud lumps bear numerous fissures and some normal faults, fine examples of block faults being common. A peculiarity of many of the new mud lumps is that their surface resembles a plowed field, being covered with irregular furrows running in every direction. This effect, which has excited much wonder, appears to be the result of slight erosion on an extensively fissured surface.

One of the most significant facts concerning the mud lumps is that they contain much more clay than has been found in other parts of the Delta deposits. Borings, several of them 45 feet and many of them 35 feet deep, were sunk in the mud lumps in the fall of 1912, and they show that most of this material is structureless clay. Similar borings in other places in the region have found stratified materials containing much sand. Sandy layers also commonly occur above and below the massive clay of the mud lumps. . A radial series of borings made on a mud lump about 2 miles west of Burrwood showed that the clay decreases and the sandy material increases in thickness away from the center of the lump. This strongly suggests that the mud lumps have been produced by the lateral flowage of soft layers of clay, for no such thick strata of clay have been found elsewhere in the Delta.

The color of the clay, though generally dark bluish or greenish gray, appears to change under certain conditions to chocolate or reddish. Such tints are common along cracks and are developed in some of the cones built up by the springs on the lumps. On drying, the gray clay becomes somewhat lighter in color and crumbles, as shown in Plate III, $A$. In this behavior and in its general appearance it resembles the "buckshot" clay of northern Louisiana and adjacent territory and the very sticky and somewhat mucky clay that is commonly deposited in marshes. The clay is so stiff that even where wet one may walk upon it without sinking more than a few inches; in fact the surface of the mud lumps is the firmest to be found below Head of the Passes. Hence, although the mud-lump islands are easy to reach and cross the lumps surrounded by marsh are very difficult of access.

In the hope that organisms or organic remains might be found in the clay which would show whether it is of marine or fresh-water origin, seven samples were examined by Dr. Albert Mann, of the United States Bureau of Plant Industry, a special search being made for diatoms. Concerning them he says: 


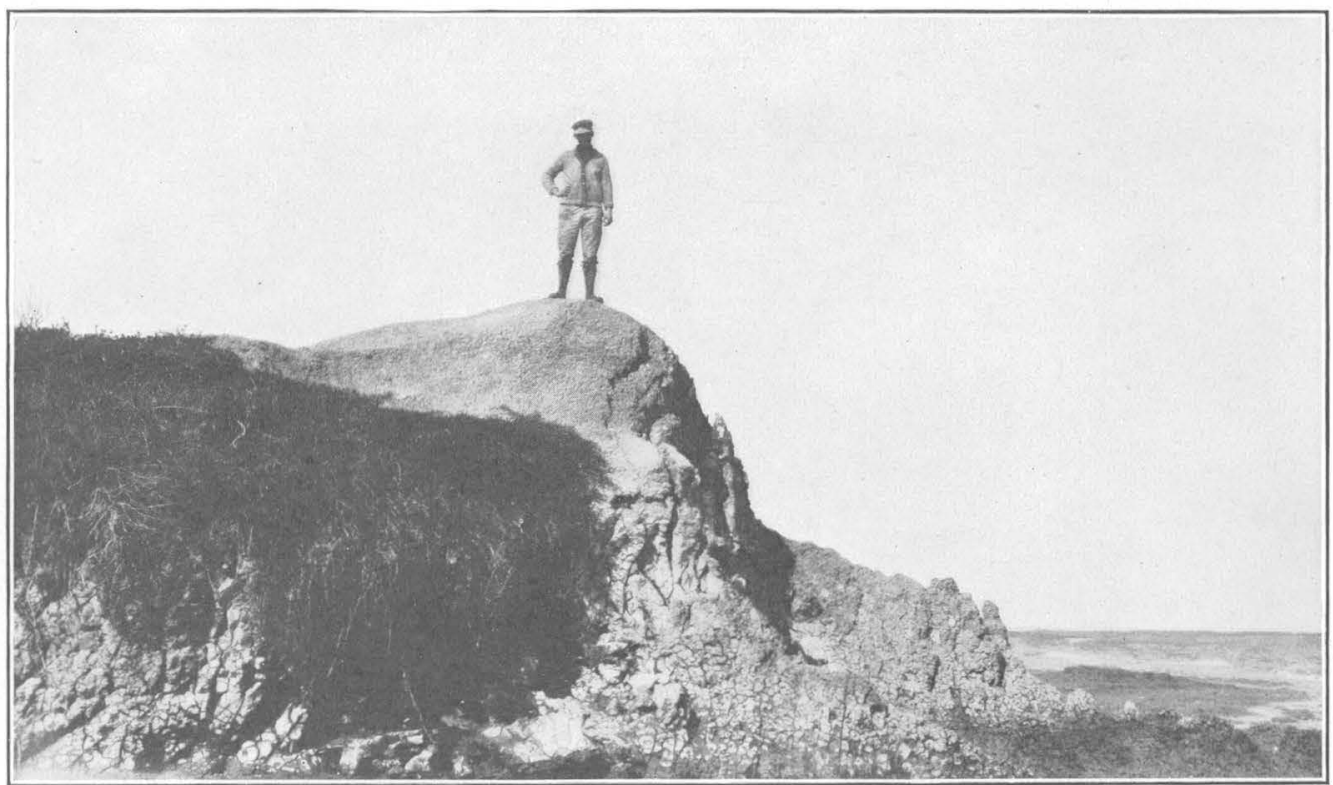

A. WAVE-CUT CLIFF ON GIBRALTAR MUD LUMP, RED FISH BAY.

The mound on which the man stands was built by a mud spring now extinct, and its crest is nearly 15 feet above mean tide, a height considerably greater than most mud lumps attain. On the left is shown a luxuriant growth of grass such as commonly flourishes on mud lumps.

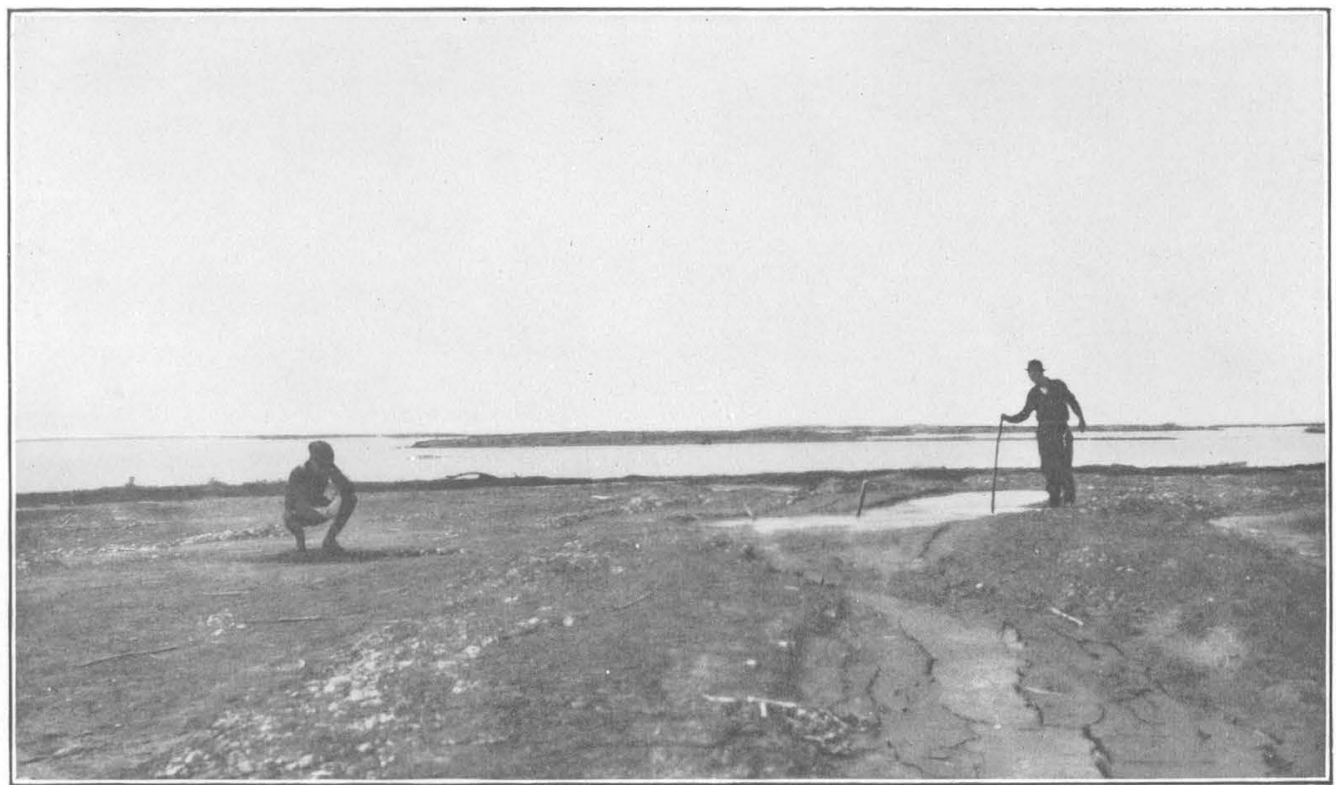

B. MUD LUMP $3 \frac{1}{2}$ MILES SOUTHEAST OF PASS A LOUTRE LIGHTHOUSE.

The men stand beside mud springs each of which is associated with a fissure. In the distance are other mud-lump islands. 
None of these samples are in any true sense mud containing diatoms. * * * I am not at all certain that all the diatoms here listed would not be found in any sample of mud located in or near the mouth of a river. $* * *$ The rare specimens of diatoms discovered by great labor are not sufficiently frequent to indicate a marine or fresh-water origin for any of the material.

\section{MUD SPRINGS.}

Among the most conspicuous and impressive features of the mud lumps are the mud springs that are active on many if not all of them. (See Pl. I, C.). The discharge from these springs consists of salt, watery mud (sludge), and gas. The amount of sludge discharged is very small and the flow of gas is only 5 to 10 cubic feet an hour. When placed in a bottle the sludge settles readily, leaving clear water at the top. Owing probably to evaporation and to a variable admixture of rain water the saltness of this water ranges from somewhat more to somewhat less than that of sea water. The mud slowly accumulates around the vents and forms cones ranging in height from a few inches to several feet (see Pl. III, $A$ ), resembling miniature volcanoes.

Careful examination reveals the fact that many and perhaps all of the gas-mud springs are closely associated with fissures. (See Pl. III, B.) Commonly the fissures are so nearly oblitcrated that it is difficult to make sure of this fact, but on the freshest lumps both the association of the springs with fissures and their absence between fissures are evident. It seems, therefore, that when a lump is pushed up its upper part, especially the sand and silt cap, is somewhat extensively fissured. Water rises in the fissures at least to the level of the sea, and gas bubbles rise through the water, causing erosion of the sides of the fissure. In places along fissures where conditions are favorable the rise of gas bubbles causes sufficient erosion to keep a vent open long after the remainder of the fissure closes entirely. The delta materials contain a large amount of both marsh gas and water, so that wherever a hole a few feet deep is made it almost immediately fills with water and bubbles with gas.

The following considerations seem to militate against the idea that the sludge discharged by the springs comes from a buried thick layer of flocculated clay. (1) The sludge settles readily, leaving clear water at the top. (2) The flow is small, irregular, and long continued. (3) The sludge in each spring has the color of the surrounding material. Two miles west of Burrwood there are two springs less than 100 feet apart, in one of which the sludge is yellowish and in the other nearly black. In the former the sludge rises through laminated yellowish silt and in the latter through dark-gray clay. (4) The bottoms of several mud lumps of various ages seem to have been reached and no layer or reservoir of sludge has been found.

It may be added that similar springs are associated with fissures elsewhere-for example along Stecles Bayou, just north of Vicksburg. Here the springs rise in fissures in an oversteepened bank. Where the quantity of water is considerable a clear stream flows from a small depression like an ordinary spring, but where it is small and the water emits bubbles of marsh gas the sides of the vent are eroded; the water becomes very muddy, and the slight overflow, accompanied by evaporation and absorption of water, leads to the growth of cones.

This hypothesis of the origin of the mud springs seems to be further supported by the fact that the vents are commonly constricted at the top, where they are only at certain times covered with the bubbling fluid mud and hence subjected to less wear than the deeper parts. Most of the vents are only a few inches in diameter at the top but widen to 1 or 2 feet a short distance down. The sounding rod, which was pushed down to a depth of 40 or 45 feet in many of the vents, penetrated 2 to 9 feet of thin watery mud, then thicker and thicker mud to a depth of 10 or 15 feet, where it encountered ordinary, somewhat stiff mud-lump clay, and finally, at a depth of 30 to 35 feet, stratified sand and silt.

\section{GAS EMANATING FROM THE MUD LUMPS.}

Gas escapes at many places on the surface of the Delta, the vents appearing to be most numerous and largest on and near the mud lumps, though the rate of flow rarely, if ever, exceeds a few cubic feet an hour. Gas rises in bubbles in all the mud springs, though its rate of issue varies. It also escapes from many cracks in the mud, rising bubbles being noticeable in many places in the shallow water around the lumps. 
Two samples of gas'were collected from the mud springs and on analysis; were found to consist principally of marsh gas $\left(\mathrm{CH}_{4}\right)$, mixed with some oxygen, nitrogen, and carbon dioxide. ${ }^{1}$ Other samples have been collected by E. W. Hilgard and A. L. Metz, and the analyses given by them show similar results, except that Hilgard reports no oxygen.

The results of the analyses are believed to show correctly the general composition of the gas, at least at the particular vents where the samples were taken. They appear to indicate that the gas is not of deep-seated origin but has developed within a few feet of the surface, for it lacks certain hydrocarbons commonly present in gas found deep in the earth. The principal constituent, methane $\left(\mathrm{CH}_{4}\right)$, emanates from most if not all marshes and generally carries with it minor and variable amounts of nitrogen, oxygen, and carbon dioxide, all of which are produced in the decay of vegetable matter. Hence it appears probable, though not certain, that the gas from the mud lumps is produced in the ordinary reduction process which affects plant material in marshes.

\section{CONCLUSIONS.}

The facts that the mud lumps are by far the thickest bodies of clay found in the Delta and that the clay is overlain and underlain by materials similar to those found elsewhere throughout the lower end of the Delta suggest that they are produced by a squeezing of the soft layers and an accumulation of clay from such layers in places where the pressure is less strong, and that the lumps are not upheaved by any such force as volcanism or by pressure from the accumulation of salt, sulphur, or gas below the surface.

The reasons for believing that the mud lumps are not of gaseous origin may be summarized as follows: (1) Their growth does not increase rapidly and terminate with something like an explosion through which the gas pressure is relieved. (2) Numerous borings which have recently been made have penetrated apparently to the bases of the lumps (to layers of sandy and clayey silt like those found elsewhere throughout the Delta), without opening any considerable gas reservoirs. (3) The lumps are somewhat closely associated with the ends of the passes and there would seem to be no reason for this asssociation if they were due to gas pressure. (4) The more fluid clayey layers are greatly thickened instead of thinned in the upheaval. (5) The gas given off is small in amount. (6) The lumps seem to reach equilibrium when they rise to sea level or a few feet above. If they were due to gas they would presumably not be concordant in height.

Hilgard's idea concerning the origin of the lumps-namely, that they are produced by the pressure of a heavy resistant layer upon a fluid layer below-appears to be in accord with some of the facts, but the results of borings recently made do not appear to support it, because, so far at least, no layer of fluid material has been found below the surface, but instead alternating thin layers of somewhat stiff sand and somewhat fluid clay. The process of flocculation by salt water is no doubt continually in progress, but the small percentage of clay in the sediment, the seasonal changes, and the work of littoral currents appear to prevent the accumulation of a thick body of semifluid clay. Another point in Hilgard's theory which seems open to question is his idea that the lumps rise where the current has scoured to a greater depth than before existed, thus weakening the crust of silt. (See Pl. II.) The mud lump in South Pass Channel to which he refers and also the lumps in Southwest Pass are beyond the ends of the jetties, where the bottom instead of being scoured deeper has been silted up.

The results of the recent work, though considerably more extensive than was hoped from an investigation covering so short a time, are meager. The inferences as to the significance of the data so far gathered may be incorrect, and new work may lead to conclusions very different from those which now seem most reasonable. For example, it may be found that at a depth of 50 feet or more the material is quite different from that which has so far been penetrated, that it is more fluid, and that it has played the most active part in mud-lump growth.

The new hypothesis, which seems better favored by the data now in hand than any other, is that the mud lumps are produced by a gentle seaward flow of layers of semifluid clay under

1 Shaw, E. W., Gas from mud lumps at the mouths of the Mississippi: U. S. Geol. Survey Bull. 541-A, pp. 12-15, 1913. 
- the land and the shallow water near the ends of the passes, where this flow is opposed by the comparatively resistant parts of the foreset beds. The tendency to flow is assumed to be due to pressure developed by constant additions of sediment. Between the passes, where the material is clayey and very yielding, this flow may reasonably take place without much upward buckling anywhere, but near the ends of the passes, where wave and current action sort the sediment and carry away some of the fine particles, leaving the more resistant material, the material is more sandy and resistant. Also there is a greater lack of equilibrium between the heavy land on the one side of a well-defined line and the water-only about half as heavy-on the other than there is between the passes, where the angle between the top and front of the Delta is not nearly so well defined. It seems reasonable to suppose that in places along the border between the comparatively resistant and steeply dipping parts of the foreset beds and the clay-bearing beds toward the land the pressure may be relieved by upward buckling accompanied by great thickening of the clay. Such phenomena are not rare. The flowage of semifluid clay has been frequently observed. It sometimes causes' great difficulty in railway building or gives rise to surprising changes in swamps. The unequal and intermittent settling of jetties, though they are well founded on large willow mattresses, also suggests squeezing and flowage. This settling has caused the abandonment of concrete for jetty building and a return to the use of large blocks of crushed stone. The mud lumps appear to be the product of flow, because in no other places have such thick bodies of clay been found, and the facts that they occur almost exclusively near the ends of the passes-most commonly west of them, where probably the principal part of the sediment is being deposited-and that they are most active during and after times of high water seem to be in accord with the hypothesis here presented.

The full details of the process will probably not be known until much more field work has been done. Perhaps if the origin of the mud lumps can be learned, their formation in places where they are objectionable may be prevented by shifting the locality of deposit or by modifying in some way the distribution of the sediment. The fact that other large deltas are without mud lumps appears to offer encouragement that a solution of the problem may be found. 